\title{
Periodicities of paleoclimate variations in the first high-resolution non- orbitally tuned grain size record of the past 1 Ma from SW Hungary and regional, global correlations
}

\author{
Pál Sümegi ${ }^{\mathrm{a}, \mathrm{b}}$, Sándor Gulyás ${ }^{\mathrm{a}, *}$, Dávid Molnár ${ }^{\mathrm{a}}$, Balázs P. Sümegi ${ }^{\mathrm{a}, \mathrm{c}}$, Tünde Töröcsik ${ }^{\mathrm{a}, \mathrm{c}}$, \\ Peter C. Almond ${ }^{\mathrm{d}}$, Ian Smalley ${ }^{\mathrm{e}}$, Liping Zhou ${ }^{\mathrm{f}}$, Lidija Galovic ${ }^{\mathrm{g}}$, Elemér Pál-Molnár ${ }^{\mathrm{h}}$, \\ Qingzhen Hao ${ }^{\mathrm{i}}$, Mihály Molnár ${ }^{\mathrm{c}, j}$, László Koloszár ${ }^{\mathrm{k}}$
}

${ }^{\text {a }}$ University of Szeged, Department of Geology and Paleontology, Szeged, Hungary

${ }^{\mathrm{b}}$ Institute of Archeology, Hungarian Academy of Science, Budapest, Hungary

${ }^{\mathrm{c}}$ ICER Center, Institute of Nuclear Research, Hungarian Academy of Sciences, Debrecen, Hungary

${ }^{\mathrm{d}}$ Lincoln University, Lincoln, Northern Canterbury, New Zealand

${ }^{\mathrm{e}}$ University of Leicester, Department of Geography, Great Britain

${ }^{\mathrm{f}}$ University of Beijing, Department of Geomorphology and Quaternary Geology, China

${ }^{\mathrm{g}}$ Geological Institute of Croatia, Zagreb, Croatia

${ }^{\mathrm{h}}$ University of Szeged, Department of Minerology, Petrology and Geochemistry, Szeged, Hungary

${ }^{\mathrm{i}}$ Institute of Geology and Geophysics, Chinese Academy of Sciences, Beijing, China

${ }^{\mathrm{j}}$ Institute of Nuclear Research, Hertelendi Laboratory of Environmental Sciences, Debrecen, Hungary

${ }^{\mathrm{k}}$ Hungarian Geological and Geophysical Institute, Budapest, Hungary

\section{A R T I C L E I N F O}

\section{Keywords:}

Past aeolian dynamics

Cycles

Loess grain-size

Middle \& Upper Pleistocene

Hungary

\begin{abstract}
A B S T R A C T
This paper presents the results of grain-size analyses of an independently-dated loess/paleosol record dating back ca. $1 \mathrm{Ma}$ from SW Hungary. The record follows an upward coarsening trend with a clear prevalence of coarse silts and fine sands. Variations are mainly controlled by fluctuations in sand input highlighting iterative changes in dust aerodynamics over the past $1 \mathrm{Ma}$ in the source region found $50-100 \mathrm{~km} \mathrm{NW}$ of our site. Based on our results regional factors influenced the intensity and nature of dust accumulation. Contrasting trends with the Chinese Loess Plateau in certain periods reflect a greater importance of the Atlantic region driving the evolution of nearby continental ice sheets. Proximity and expansion of these had significant impact on local wind field. Low topography of the surrounding mountain belts allowed for the intrusion of stronger cold winds, higher abrasion in the source region and transportation of coarser particles to the site from 700 to 450 ka. Another marked upward increase in grain-size from 400 ka can be linked to increasing continentality which along with tectonic activity resulted in a drop in the groundwater table in the source region and intensified erosion of formerly relatively stable surfaces bringing more coarse material to our site.
\end{abstract}

\section{Introduction}

Various climatic forcings in the past resulted in different responses at a regional level during the Quaternary (Imbrie et al., 1993; Kageyama et al., 2012; Kohlfeld and Harrison, 2000; Schmidt, 2010; Lang and Wolff, 2011; Rapp, 2012). Understanding the leads and lags between proxy archives is crucial to understand feedbacks in Earth's climate system. Long and high-resolution terrestrial paleoarchives yielding us information on past climatic fluctuations over several glacial-interglacial cycles on the millennial scale are rare. Loess can represent such a semi-continuous terrestrial paleoenvironmental record (Pécsi, 1990; Pye, 1995). The substantial loess deposits of the Middle and Lower Danube Basin in southeastern Europe are the thickest and most complete terrestrial paleoenvironmental records in Europe (Buggle et al., 2009, 2013; Marković et al., 2011, 2015; Jordanova and Petersen, 1999; Jordanova et al., 2007, 2008; Panaiotu et al., 2001; Rădan, 2012 Sümegi et al., 2011; Sümegi et al, 2018). Loess and paleosol sequences (LPS) of the Danube Basin go back 1 Ma (Buggle et al., 2009, 2013; Jordanova and Petersen, 1999; Jordanova et al., 2007, 2008; Marković et al., 2011, 2015; Sümegi et al., 2011; Sümegi et al,

\footnotetext{
* Corresponding author.

E-mail address: gulyas.sandor@geo.u-szeged.hu (S. Gulyás).
} 
2018). The wealth of studies dealing with the comprehensive analysis of these paleoarchives yielded information on chronology, stratigraphy, geochemistry, paleoecology, as well as environmental magnetic characteristics of these sites on the scale of multiple millennia (Fitzsimmons et al., 2012; Marković et al., 2011, 2015; Sümegi et al., 2011, 2018). However, most multiproxy studies published so far from Mid-Danube Basin sites are either low resolution, or use only a single -mainly magnetic susceptibility- proxy or two (e.g. Marković et al., 2011, 2012; Sümegi et al., 2018). Multiproxy studies are mostly restricted to the period of the last glacial cycle (Antoine et al., 2009a,b; Bokhorst et al., 2011; Novothny et al., 2011; Stevens et al., 2011; Schatz et al., 2011, 2014, 2015; Zech et al., 2013) as establishing an independent chronology beyond $300 \mathrm{kyr}$ down to ca. $1 \mathrm{Ma}$ is not without problems as direct luminescence dating is difficult due to technical problems or age is established by correlation to some other global or orbital records (Schmidt et al., 2010; Murray et al., 2014; Thiel et al., 2014; Marković et al., 2015; Obrecht et al., 2016; Wacha and Frechen, 2011; Wacha et al., 2013; Sümegi et al., 2018; Zeeden et al., 2016). Some works use artificial composite sections made via stitching together proxies of two or more adjacent sites with different temporal coverage to attain a full coverage of 700-800 ky (Buggle et al., 2013; Marković et al., 2012, 2015). Others rely on orbitally tuned records to find orbital cycles (Marković et al., 2012; Basarin et al., 2014). Thus, chronological issues related to these studies generally prevent us from undertaking a widescale reliable comparison (Sümegi et al., 2018, Zeeden et al., 2018).

Loess grain size is one of the most common proxies used to reconstruct environmental and climatic conditions driving aeolian accumulation in LPS over several glacial/interglacial and millennial timescales (Vandenberghe et al., 1998; Bokhorst et al., 2009, 2011; Újvári et al., 2014, 2016, Schulte et al., 2018; Xiao et al., 1995, Lu and An, 1998; Sun et al., 2006; Ding et al., 2002). Grain size distribution is a function of complex interactions between various factors like wind speed, frequency of storm events, moisture availability in source and sink areas, distance of source areas, type of transport mechanism, sediment availability, mineral composition, vegetation cover in source regions and post-depositional processes (Smalley and Markovic, 2014; Stevens et al., 2013, 2018; Schulte et al., 2018; Újvári et al., 2016). This study presents the first independently dated, high-resolution grain size record of one of the oldest and thickest loess/ paleosol sequence of Hungary, the borehole Udvari 2a. Dating was based on biostratigraphically controlled independent magnetostratigraphic ages beyond 50 ka down to $1.1 \mathrm{Ma} .{ }^{14} \mathrm{C}$ ages helped us to constrain the chronology in the youngest part of the sequence (Sümegi et al., 2018). Spectral and wavelet analysis of grain-size fractions enabled us to unravel regional cycles of past aeolian dynamics spanning the past $1 \mathrm{Ma}$. Differences between the loess areas are due to different responses of regional climate systems to the global climate and different contributions of dust availability, erosion, tectonic uplift and local environmental conditions, including vegetation cover and soil formation (Smalley and Markovic, 2014; Stevens et al., 2013, 2018; Schulte et al., 2018; Zeeden et al., 2018). Thus, comparison of our grain-size proxy data and results of cycle analysis with other regional (Danube Basin) and extra regional (SW and SE Europe, China) grain size and paleoclimate records is essential to highlight similarities and differences with potential underlying causes.

\section{Location, climate, lithostratigraphy, chronology of the site}

The borehole Udvari-2A is found in the central plateau part of the Tolna Hills, SW Hungary (Fig. 1). The climate is temperate (Köppen Bs) with strong oceanic (Köppen Cf) and sub-Mediterranean climatic influences. This site is located at an interface between drier and wetter climates mainly seen in higher temperatures, multiple rainfall peaks and elevated hours of sunshine. The mean annual temperature is around $9-9.5^{\circ} \mathrm{C}$ with average annual precipitation reaching $700-750 \mathrm{~mm}$ in the western part of the hills, where the borehole site is located (Ádám et al., 1981; Hungarian Meteorological Survey). Rainfall and humidity are much higher than the southern Vojvodinian (Serbia) sites (ca. $500 \mathrm{~mm} / \mathrm{y}$; Obrecht et al., 2016). The prevailing winds in the area are from the NW (Ádám et al., 1981, Hungarian Meteorological Survey).

The borehole starts from an elevation of $178 \mathrm{~m}$ ASL in a clear plateau position with a depth of $170.3 \mathrm{~m}$ (Fig. 1). A sequence of $150 \mathrm{~m}$ dated to the Quaternary overlies Miocene deposits (Fig. 1). The upper $97 \mathrm{~m}$ represent the Paks Loess Formation (Koloszár, 1997, 2003; Koloszár and Marsi, 2010a,b.; Sümegi et al., 2018) according to the generally accepted Hungarian Quaternary Stratigraphic and Pedostratigraphic Scheme (HQSPS; Pécsi, 1979, 1993; Pécsi et al., 1995; Sartori et al., 1999; Újvári et al., 2014; Varga, 2011).

The newly revised stratigraphy (Sümegi et al., 2018) identified 13 paleosols (U2-S0 and U2-S13) within the whole Pleistocene sequence down to the depth of $100 \mathrm{~m}$ corresponding to MIS 1-MIS 33 (Fig. 1).

A revised chronology has recently been presented for the site, which is adopted in our work (Sümegi et al., 2011; Sümegi et al. 2018; Fig. 1).

The bottom part of the sequence is characterized by reversed polarity representing the Matuyama Chron with several short normal polarity excursions. These correspond to the Kamikatsura excursion dated around $0.9 \mathrm{Ma}$, the Jaramillo Subchron dated between 0.99 and 1.07 Ma, as well as the Olduvai Subchron (1.77-1.95 Ma; Márton, 1998; Koloszár, 2003; Koloszár and Marsi, 2010a,b, Sümegi et al., 2018). The Brunhes Chron in the upper part of the LPS is represented by the Matuyama-Brunhes Boundary (MBB; Márton, 1998; Koloszár, 2003; Koloszár and Lantos, 2001; Koloszár and Marsi, 2010a,b; Koloszár et al., 2001; Sümegi et al., 2018) and several short-lived reversed polarity excursions like the stage 17 excursion (0.670-0.685 Ma; Sümegi et al., 2018; Biswas et al., 1999; Channel and Raymo, 2003; Laj and Channell, 2009; Singer, 2015), an unnamed event at $430 \mathrm{ka}$ and the Levantine excursion dated around $362 \mathrm{ka}$ (Sümegi et al. 2018.; Langereis et al., 1997; Lund et al., 2001, 2006; Laj and Chanell, 2009). The other shortlived reversed polarity events correspond to the MIS6/MIS7 transition (Iceland Basin excursion at $191 \mathrm{ka}$ ) and the Blake excursion (ca. $120 \mathrm{ka}$ ), respectively (Sümegi et al., 2018). The uppermost $4 \mathrm{~m}$ of the sequence corresponds to the period between ca. 45 and $15 \mathrm{ka} \mathrm{cal} \mathrm{BP}$ based on ${ }^{14} \mathrm{C}$ dates (Sümegi et al., 2018). The presence of a Middle Pleistocene index fossil in the sequence helped us to further constrain the chronostratigraphy from MIS 6 to MIS 10 (Sümegi et al., 2018).

\section{Material and methods:}

\subsection{Sampling and sample description}

Our sampling was restricted to the upper $86 \mathrm{~m}$ of the core (344 samples) corresponding to the last ca. 1 Ma (MIS 1-MIS 27; Sümegi et al., 2018). Samples of ca. $60 \mathrm{~g}$ were taken at $25 \mathrm{~cm}$ increments. Samples were air dried and their color was determined using the Munsell color chart. Furthermore, the main visual characteristics of the samples was also described.

\subsection{Grain size measurement}

Grain size analyses were performed on an OMEC Easysizer 20 laser wet dispersion particle size analyzer after sample pretreatment. The instrument is equipped with a circulating wet sample feeding system. A single, a red He-Ne laser of $2.0 \mathrm{mw}$ at a wavelength of $0.6328 \mathrm{~mm}$ is used in the system. The instrument adopts the full Mie theory. Diffracted light intensity was measured by 54 sensors over a wide range of angles. The measuring range of the unit is $0.1-500 \mu \mathrm{m}$. Constants of 1.33 for the refractive index of water, 1.544 for the refractive index of solid phases (valid for quartz, and most clay minerals and feldspars), and an absorption index of 0.1 was applied. Ultrasonic duration with a circulating speed of 2500 was set to $2 \mathrm{~min}$. Repeatability is within < $3 \%$ uncertainty. One gram of sample was treated with $10 \mathrm{ml} 10 \% \mathrm{H}_{2} \mathrm{O}_{2}$ 


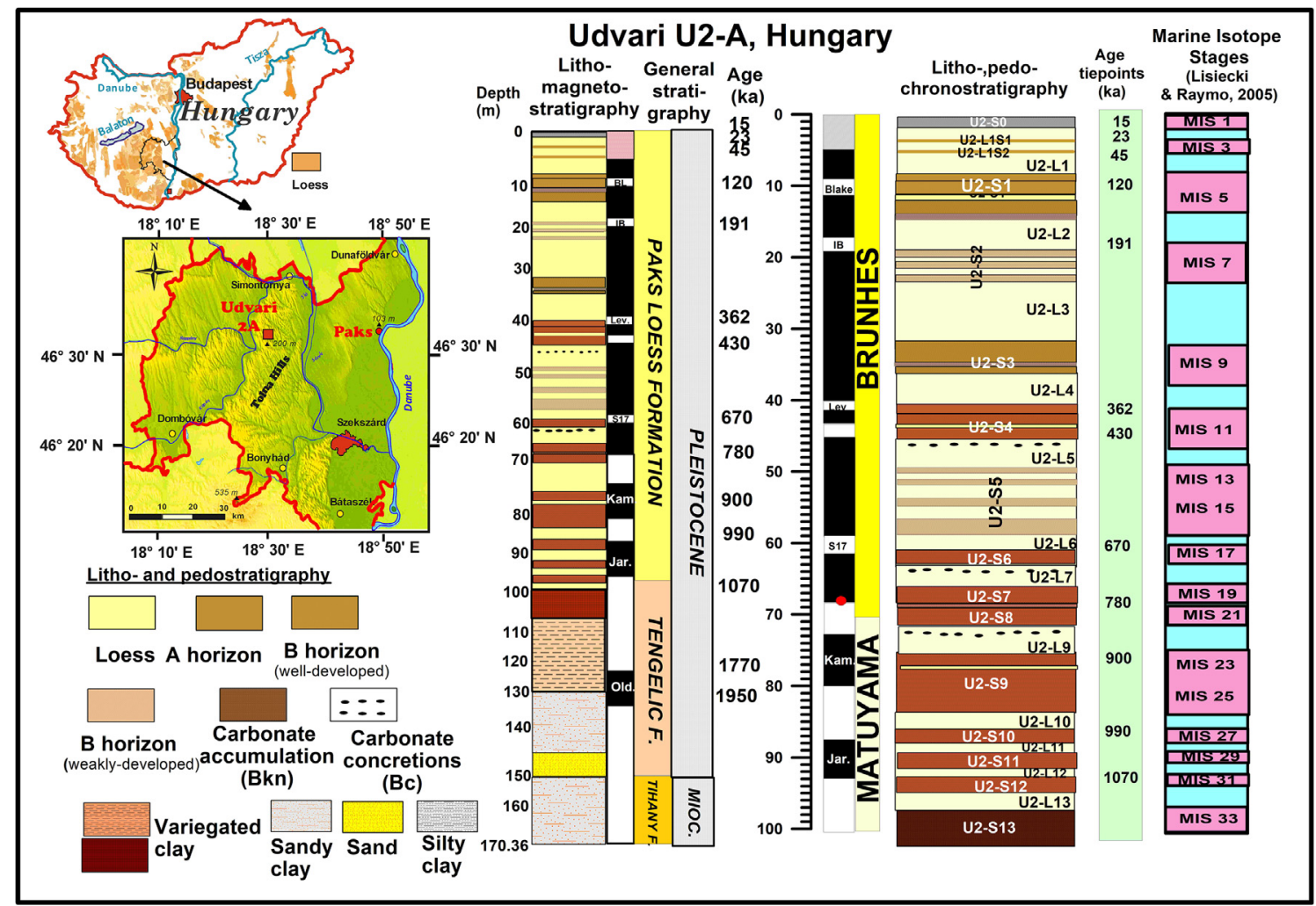

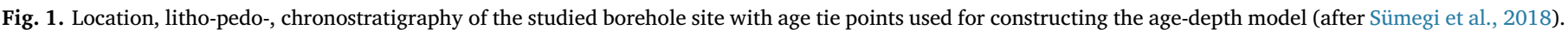

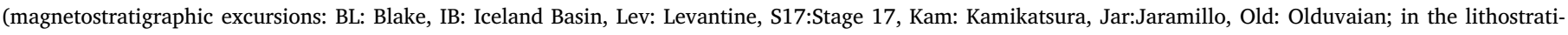
graphic column S1,2.etc. represents interglacial soils, while L1,2..etc. corresponds to glacial loess).

in a $50 \mathrm{ml}$ glass beaker overnight to remove organic materials. Then it was treated with $10 \%$ HCL overnight to remove carbonates. Pre-treated samples were dispersed in $50 \mathrm{ml}$ solution adding $5 \%$ sodium hexametaphosphate $\left(\left(\mathrm{NaPO}_{3}\right)_{6}\right)$ to avoid grain flocculation and were kept agitated using an ultrasonic bath and a propeller stirrer before transferring into the measurement unit. Grain-size classes were determined in accordance with the Wenthworth scale of grain-size distribution. However, for the clay fraction the upper boundary of $4.6 \mu \mathrm{m}$ was considered in accordance with the general practice used in laser particle size analysis (Vandenberghe et al., 1998).

\subsection{Particle size distribution analysis}

Particle-size distributions are frequently used to capture the composition of the studied sediment and decipher information about conditions responsible for the transportation and deposition of the individual grains. Most studies present a few parameters for the description such as the median and maximum grain-size or the fraction below or above a certain grain-size class $(16 \mu \mathrm{m}, 32 \mu \mathrm{m}, 64 \mu \mathrm{m}$; e.g. Xiao et al., 1995, Lu and An, 1998; Sun et al., 2006; Ding et al., 2002). Other parameters describing the nature of the distribution (skewness and kurtosis) should also be considered (Zech et al., 2008).

Schulte et al. (2018) also argued against the use of individual grainsize parameters alone. Defining fixed indices or ratios between different grain-size classes is also commonly used in loess particle-size studies (Vandenberghe et al., 1998; Antoine et al., 2001, 2002; Nutgeren and Vandenberghe, 2004). Adoption of these is based on the assumptions that changes in wind strength are likely to cause shifts in the grain-size maximum values by adding an increasing number of larger-size particles (coarse silt or even fine sand) to the originally deposited set of finer fractions. Thus, indices reflecting the ratio of coarse fractions to fine ones are the most commonly used as proxy for wind velocity. Schulte et al. (2018) in their work warned against the use of a single fixed grain size (GS) ratio in temporal data analysis, stating that GS distribution of one sample expresses variability in the dominant GS classes rather than specific traceable parameters of past environmental conditions. Nevertheless, their study clearly pointed out that although different grain size proxies may be dominated by different single parameters, their variation with depth down an LPS is very similar (Schulte et al., 2018). Thus, in our work two indices have been adopted. One is the socalled U-ratio defined as the ratio of 16-44 and 5.5-16 $\mu \mathrm{m}$ size classes (Vandenberghe et al., 1998). The other is the Grain Size Index (GSI) (Antoine et al., 2002, 2009a,b, 2013). This is defined as the ratio of coarse silt $(20-50 \mu \mathrm{m})$ to fine silt + clay $(<20 \mu \mathrm{m})$. One advantage of the U-ratio index is that it ignores both the secondary formed clay minerals and the sands deposited at the site.

However, the sand content also provides important information about predominating wind regimes, proximity of source areas, as well as short events triggered by abrupt increases in aeolian dynamics (Novothny et al., 2011). Also, recent studies have pointed to an erroneous interpretation of generally accepted models of particle transportation suggested by Pye (1995) and Újvári et al. (2016) (Schulte et al., 2018). For coarse grains, grain mass and rapid gravitational settling is thought to limit long-range transportation. However, several studies documented the presence of quartz particles above the fine sand size $(>150 \mu \mathrm{m})$ in long-range transported aeolian dust (Middleton and Goudie, 2001; Fiol et al., 2005; Alcántara-Carrió et al., 2010; Menéndez et al., 2014). Furthermore, Rosenberg et al. (2014) reported no correlation between GS fractions below $40 \mu \mathrm{m}$, wind speed or distance from assumed source (Schulte et al. 2018). Thus, an additional index (Fine sand/fine silt) for aeolian dynamics has also been developed taking into consideration the sand fraction in relation to the fine silt fraction. Median size (MD) parameters as well as the main univariate statistical parameters of skewness and kurtosis have also been calculated. In addition, percentages of selected grain size classes of clay $(<4.6 \mu \mathrm{m})$, coarse silt $(22.6-63 \mu \mathrm{m})$ and sand $(>63 \mu \mathrm{m})$ have been determined and 
graphed in accordance with the literature (Antoine et al., 2001, 2002, 2009b; Konert and Vandenberghe, 1997). To assess the similarity of information recorded by the mentioned parameters and indices, and to reduce potential biases mentioned by Schulte et al. (2018), statistical correlations (Spearman rho) have been calculated.

\subsection{Age-depth models}

During the construction of our age-depth model, a continuous sedimentation was assumed. Short-periods of non-deposition are not assumed as these represent so-called debunked soil forming intervals when paleosols form as an interaction of slow deposition and climatic influences (Sümegi et al. 2018) as noted by studies of modern upbuilding pedogenesis under active loess deposition (e.g. Eger et al., 2012). So even during times when downward pedogenesis created welldeveloped paleosols, sediment accumulation did not fully stop. Paleomagnetic ages used for the construction of the model generally bracket paleosols (Fig. 1). Thus, the ages in our model correspond to ages of the sediment itself. A 7th order polynomial age-depth model (Fig. S1) has been constructed using the age tie points presented in Fig. 1 (for detailed list see Table 2. in Sümegi et al., 2018). A bootstrap for the mean probability distribution response of paleomag ages of 20,000 iterations was performed to calculate $95 \%$ confidence intervals.

\subsection{Spectral and wavelet analysis of fixed grain-size indices}

Traditional time series analysis was conducted on all calculated grain-size indices using REDFIT, and spectral peaks were evaluated against a red-noise background (Monte Carlo using 1000 random realizations) of an AR1 process (Schulz and Mundelsee, 2002). REDFIT uses Lomb-Scargle Fourier transform, which allows using unevenly spaced datasets (Schulz and Mundelsee, 2002). Application of the simple Lomb periodogram in time-series analysis has a significant drawback in comparison with the REDFIT method. For the calculation of the $p=0.5$ significance line only the highest peak is considered, while REDFIT uses all peaks equally relying on an AR algorithm (Schulz and Mundelsee, 2002). That is why REDFIT was preferred in our work.

To track the time-varying amplitude of orbital and suborbital periods, continuous wavelet transform has been calculated on detrended data (Torrence and Compo, 1998). The time series was tested for a significant trend using the Mann-Kendall test (Gilbert, 1987). For wavelet analysis a time series was prepared by Gaussian interpolation to a fixed time increment of $1 \mathrm{kyr}$. The statistical significance of the wavelet analysis was tested relative to a red-noise background spectrum.

\section{Results}

\subsection{Results of grain-size distribution analyses}

Particle size follows a multi-modal distribution for all sampled loess horizons as depicted in Fig. 2. This polymodal distribution is typical for loess/paleosol sequences with a pronounced shift to the coarser grain sizes (Antoine et al., 2001, 2002, 2009a,b; Bokhorst et al., 2011; Varga, 2011; Novothny et al., 2011; Machalett et al., 2008). There is a prominent double peak representing the coarse fraction (coarse silt + sand) and a wide tail representing the fines of fine silts and clay. In the MIS 2, 4, 10,18, 22 loess samples, a clear dominance of coarse silt is noted compared to sand (fine silty coarse silt; Fig. 2). A bimodal silt peak can also be noted in these and all other loess samples of Fig. 2. This distinctive feature has yet been documented for a single site in Central Asia so far (Machalett et al., 2008), and thus was interpreted to be a regional phenomenon related to mineral composition or, perhaps, an instrument-specific artefact (Schulte et al., 2018). In the MIS 2, 6, 8, 12 loess samples fine sand dominates over coarse silt (sandy coarse silt; i.e. sandy loess). The bimodal silt peak is also present, but in some cases one peak is absorbed into the distribution of the clay fraction (Fig. 2). In the MIS 16 loess sample the proportion of coarse silts and fine sands is relatively similar, yet two minor distinct peaks can be distinguished as well.

Variations in selected grain-size parameters of clay, coarse silt, fine sand, medium and coarse sand as well as parameters representing general grain-size distribution-median particle size, skewness (SK) and kurtosis (K) with depth are depicted in Fig. 3. There is a relatively good agreement of the grain-size parameters with the initially established stratigraphy. The major litho- and chronostratigraphic boundaries (from paleosols to overlying loess units) are generally recorded by abrupt transitions in the grain-size parameters. The main grain-size variations and contrasts are observed in the clay $(<4.6 \mu \mathrm{m}$ : from 8 to $39 \%)$, coarse silt $(22.6-63 \mu \mathrm{m}$ : from 52 to $47 \%)$ and sand fractions ( $>63 \mu \mathrm{m} .12-2 \%$ ). It is interesting to note that variations in the median grain size seem to show a closer correlation with the sand fraction (Spearman rho: 0.97) than the coarse silt fraction (Spearman rho: 0.37). Therefore, grain-size variations must have been largely controlled by a constant input of sand size particles especially in the upper $60 \mathrm{~m}$ of the sequence.

There is a general upward coarsening from the bottom part of the borehole corresponding to MIS 23-27 towards the modern soil (Fig. 3). This is accompanied by a gradual decrease in clay content in general.

Clay content in the entire profile ranges between 8.28 and $39.73 \%$ with a mean of $17.41 \%$ and an SD of $5.586 \%$. The particle size distributions are non-normal (Sapphiro-Wilk test: 0.92, p:0.3238E-12), and slightly right skewed (SK:1.083) indicating the dominance of finer grain-sizes (Fig. 3). Well-developed paleosols are characterized by clay percentages of $16 \%$ up to about $29 \%$ (Fig. 3). The interquartile area is given by values of $13.5-20 \%$. The MIS 7 (U2S2) and MIS 13-15 (U2S5) paleosols have low clay contents just above the median in accordance with the field/core description of weak paleosol development. The horizons with values above $29 \%$ correspond to well-developed paleosol horizons with a high rate of pedogenetically produced clay. The clay content of the lowermost pedocomplex U2S9, corresponding to MIS 23-27, ranges between 30 and 39 percent. This is the highest value recorded in the LPS apart from the MIS 5 pedocomplex (U2S1), which is also characterized by high clay percentages around 39\%. Horizons corresponding to MIS 19-21 (U2S7, U2S8), the lowermost member of the MIS 11 (U2S4) and MIS 9 (U2S3) paleosols also fall into this category with clay values slightly above $29 \%$. The MIS 17 paleosol (U2S6) is characterized by clay values around $24 \%$. The weakly developed U2S5 pedocomplex corresponding to MIS 13-15 has low values of clay around $18-20 \%$. The percentages of coarse silt in the profile range between 39 and $72 \%$ with a mean of $61 \%$ and an SD of 5.74 . The interquartile area is given by values between $57.92 \%$ and $64.95 \%$. The distribution is slightly left skewed implying the dominance of higher concentrations of coarse silt in the samples. The gradual decrease in clay content from U2S9 to U2S5 (MIS 27 to MIS 13) is accompanied by a marked increase in the coarse silt content of the paleosols from $\sim 48 \%$ to $56 \%$. Similarly, a gradual upward increase is noted in the sand content from $2 \%$ to $10-12 \%$. This is especially pronounced from the bottom of the loess unit U2L6 to the top of U2L5 (MIS 16 and MIS 12). Nevertheless, the silt content of the intercalated loess horizons stays relatively constant up to U2L6, with values ranging between 57 and $62 \%$. From U2L6 to the top of U2L5 there is a gradual 10\% decrease of the coarse silt content parallel with the mentioned $8-10 \%$ rise in the sand content. From U2S3 to the top of U2L2 (MIS9-MIS 7) a similar gradual $10 \%$ decrease in the silt content is accompanied by a steady increase of the fine sand content from $2 \%$ to $10-13 \%$. Although the fine sand content decreased from the peak value of $15 \%$ recorded in the MIS 8 loess to a lower value of $8-10 \%$ in the loess representing MIS 6 , there is a parallel increase in the medium and coarse sand percentages resulting in a more peaked and positively skewed distribution. A steady rise in the sand content can be observed from MIS 5 (U2S1) towards the loess corresponding to MIS 4 (U2L1; 14\%). This increase in the sand content is accompanied by a similar increasing trend in the coarse silt 

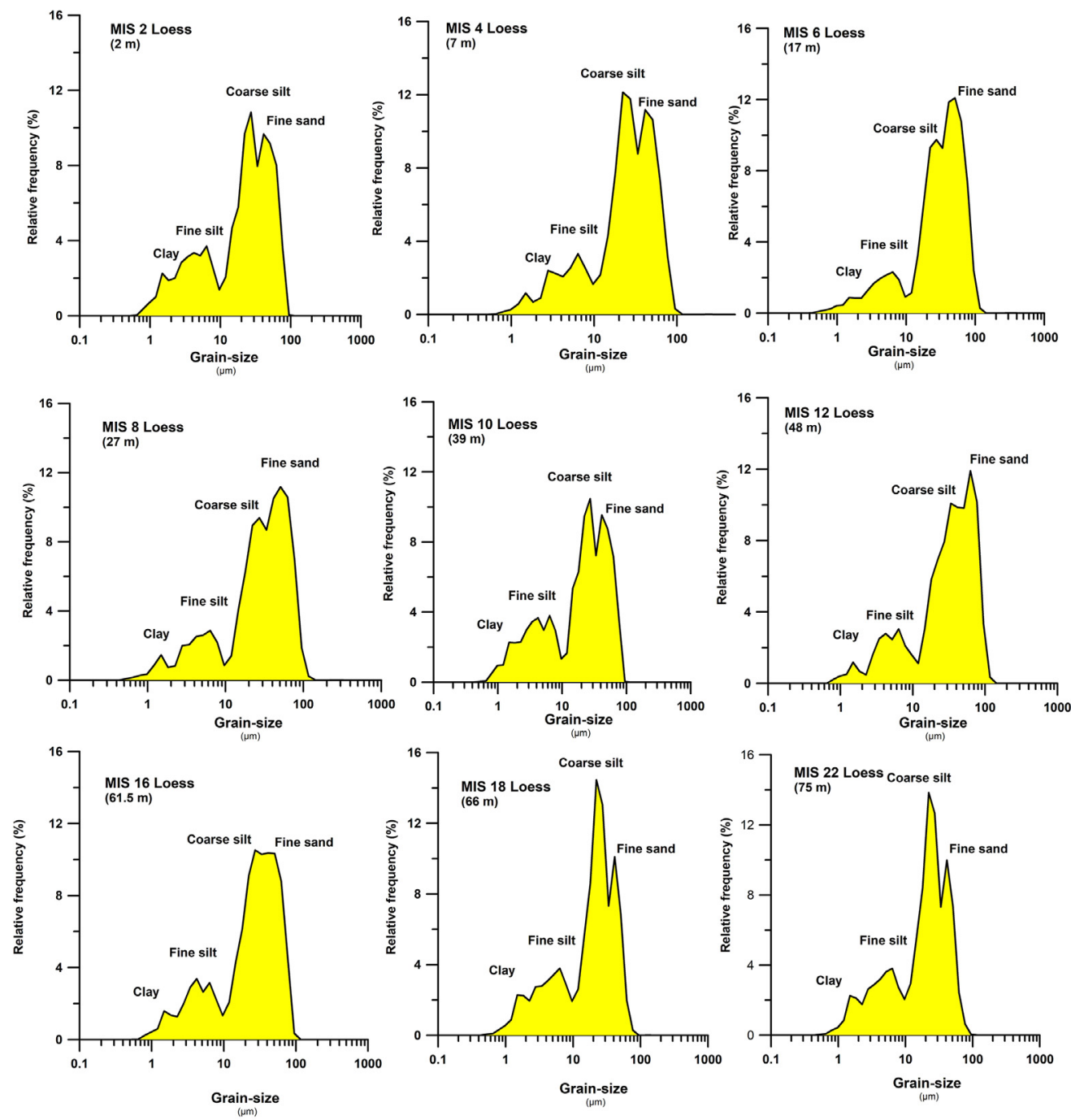

Fig. 2. Particle size frequency distribution curves for selected representative loess samples.

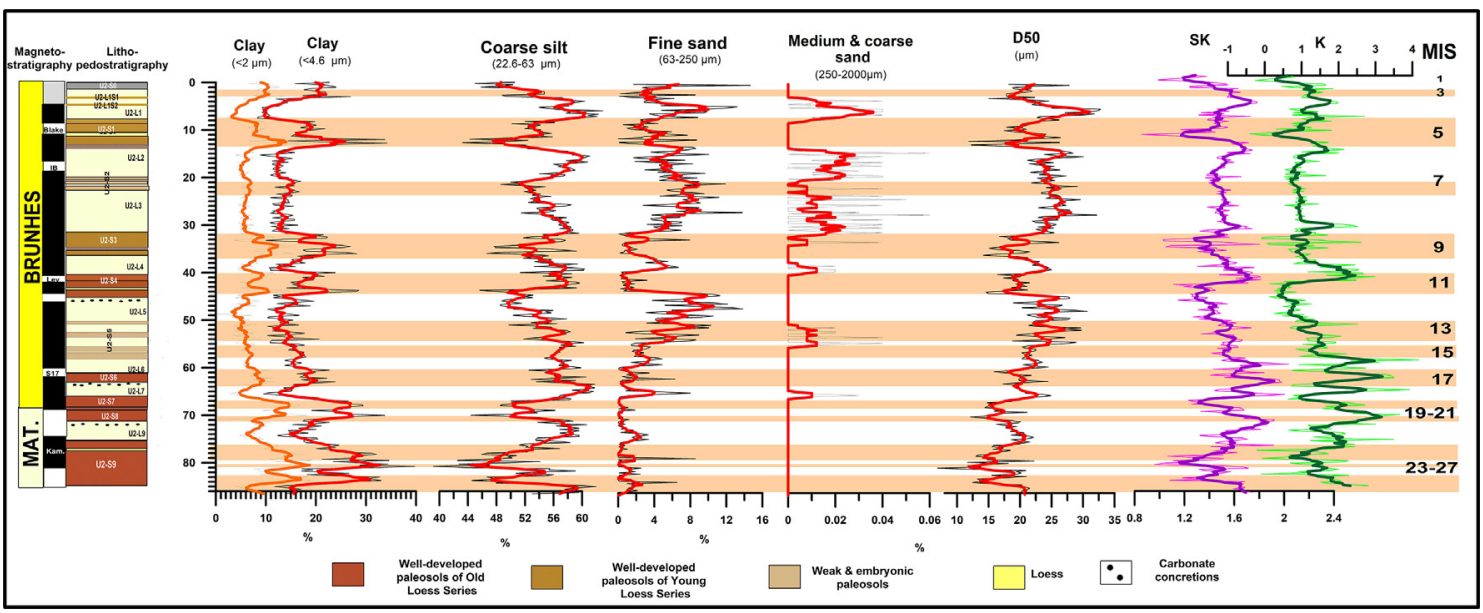

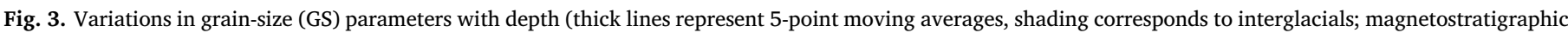

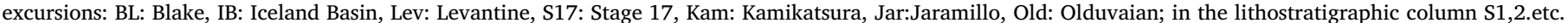
represents interglacial soils, MIS: marine isotope stages after Lisiecki and Raymo, 2005). 


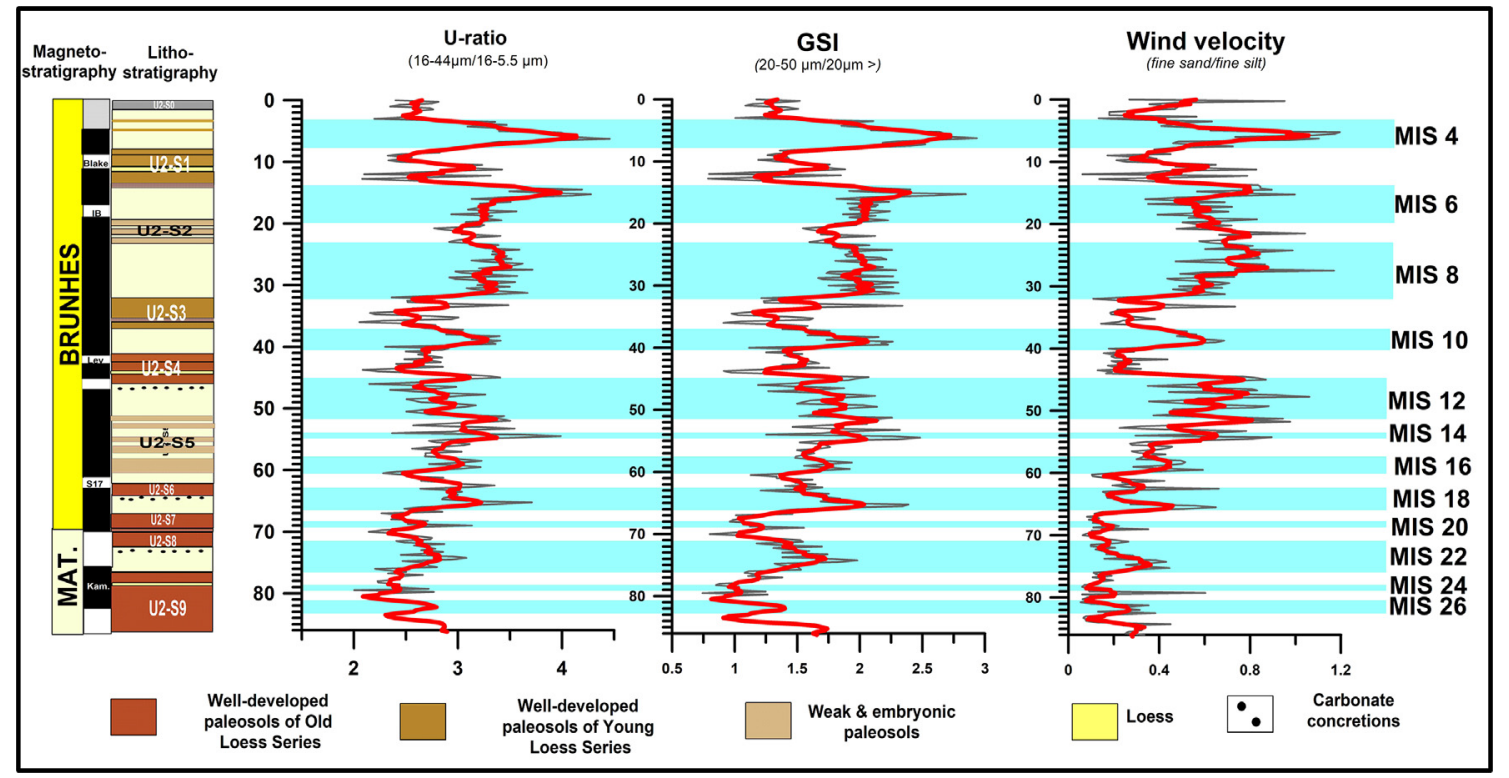

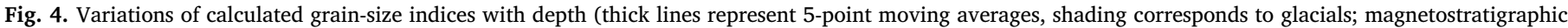

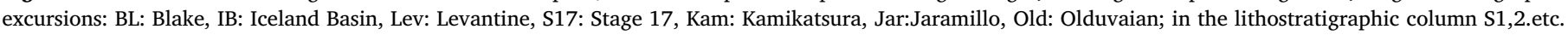
represents interglacial soils; MIS: marine isotope stages after Lisiecki and Raymo, 2005).

fraction. After this peak all mentioned grain-size classes undergo a gradual decrease towards the top of the profile. The moderately strong correlation between the sand and coarse silt content (Spearman Rho ${ }^{2}$ : 0.67 and the strong negative correlation between the clay and coarse silt (Spearman Rho $\mathrm{r}^{2}$ : -0.91 ), clay and sand (Spearman Rho $\mathrm{r}^{2}$ : -0.78 ) content respectively may refer to a dominantly pedogenetic origin of clay. Yet the low clay percentages in the weakly developed paleosols of U2S2 (MIS 7) and U2S5 (MIS 13-15) in fact may be attributed to a constant and high input of silt and sand to the site. This assumption is further corroborated by the previously noted steady increase of sand during the referred intervals.

\subsection{Variation of grain-size indices during the past $1.1 \mathrm{Ma}$}

If we look at the pattern given by the various grain-size indices (Uratio, GSI, fine sand/fine silt) we essentially see quite similar trends (Fig. 4). The high correlation between the various indices (U ratio-GSI: Spearman Rho $\mathrm{r}^{2}$ : 0.94 U-ratio to Wind Velocity: Spearman Rho $r^{2}: 0.87986$, GSI to Wind Velocity: Spearman Rho $r^{2}: 0.88$ indicates that applying either grain-size index does not lead to differences in reconstruction of past dust (transport) dynamics. The GSI and U-ratio tend to covary and seem to follow the trajectory marked by the clay and silt content of the dataset. This is also expressed in the higher positive and statistically significant correlation values between the two indices $\left(r^{2}=0.94\right.$; Table S2). Conversely, the additional so-called wind velocity index (ratio of fine sand and fine silt) follows the pattern given by variations in the sand content. These can be attributed to the nature of the applied grain-size indices. As in the case of the GSI and U-ratio, the ratio of silts and clays are given larger weight. While, in the case of the wind velocity index, the ratio of fine sand is also considered, which was omitted from the previous two indices.

All the grain size indices show an upward increase from the bottom of the profile to the loess U2L5 (Fig. 4). In the case of the U-ratio this increase is from 3 to $3.5-3.8$. In the case of the GSI it is from 1.75 to 2.25. Finally, for the fine sand/fine silt ratio index there is a similar increase from 0.4 to 0.9 . This may hint at an overall increase in wind speed, erosional activity of the source areas from the paleosol horizon of U2S9 to the loess horizon of U2S5. In addition, it indicates the importance of the silt and fine sand fraction in the upward coarsening of the dataset. All intercalated well-developed paleosols (U2S9, U2S8,
U2S7, U2S6) are corresponding to the long interglacials of this interval (MIS 27-MIS 17), and are characterized by low values for all indices (Uratio: $\sim 2.1$, GSI: $\sim 0.75$, Wind velocity: $\sim 0.1$ ). This is true for all remaining well-developed paleosols (U2S6, U2S4, U2S3, U2S1) as well. In the loess horizon U2L5 the trajectory of the individual indices is different. GSI and U-ratio undergo a gradual decrease. However, the ratio of fine sand/fine silt continues to increase, implying a higher input of sand size particles to the site. This contrasting pattern is due to the omission of the sand fraction by the GSI and U-ratio indices.

From U2L4 to the top of U2L3, the values of U-ratio and GSI remain relatively constant (3.5-3.6 and 2.25-2.26). Meanwhile, the ratio of fine sand/fine silt rises again from 0.6 to $1-1.2$. Most likely this is again attributed to a higher rate of sand input to the site. From U2L3 to the top of U2L2 both the U-ratio and the GSI underwent a rapid increase (from 3.5 to 4.2 and from 2 to 2.75 , respectively). The ratio of fine sand/fine silt after a minor increase decreased from the peak value of U2L3 towards the top of U2L2. The topmost part of U2L2 is again characterized by a minor increase. Finally, from U2L2 the trajectory of all three indices is uniform with a steady rise to the highest value of the entire profile recorded in the loess U2L1 (4.45, 2.9 and 1.2).

\subsection{Results of cycle analysis and comparison with grain-size cycles at Xifeng, China}

The highest primary spectral peaks for the U-ratio above a p $<0.05$ are at periods of $456,97 \mathrm{ky}$, both eccentricity related with the highest power found at the dominant 97-ky cycles (Fig. 5). The statistically significant eccentricity related 400-ky cycles are outside the cone of influence of the wavelet analysis in our record. However, the 100-ky cycles display strong variations in terms of intensity as seen on the left wavelet scalogram of Fig. 5. From 900 to ca. 650 ka the 100 -ky cycle was moderately strong. It was then weak during the Mid-Brunhes transition between 600 and $400 \mathrm{ka}$. From $300 \mathrm{ka}$ onwards there is a marked increase in the intensity of these cycles having a maximum from 200 ka onwards.

Additional statistically significant peaks are found at 70, 57, 48, 37, and $33 \mathrm{ky}$. These are partly obliquity related with much lower power. Partly they may originate from the harmonics or interactions of the orbital cycles, which is normal in time series analysis of paleoclimatic records (e.g. Lu et al., 2004; King, 1996), such cycles can represent 


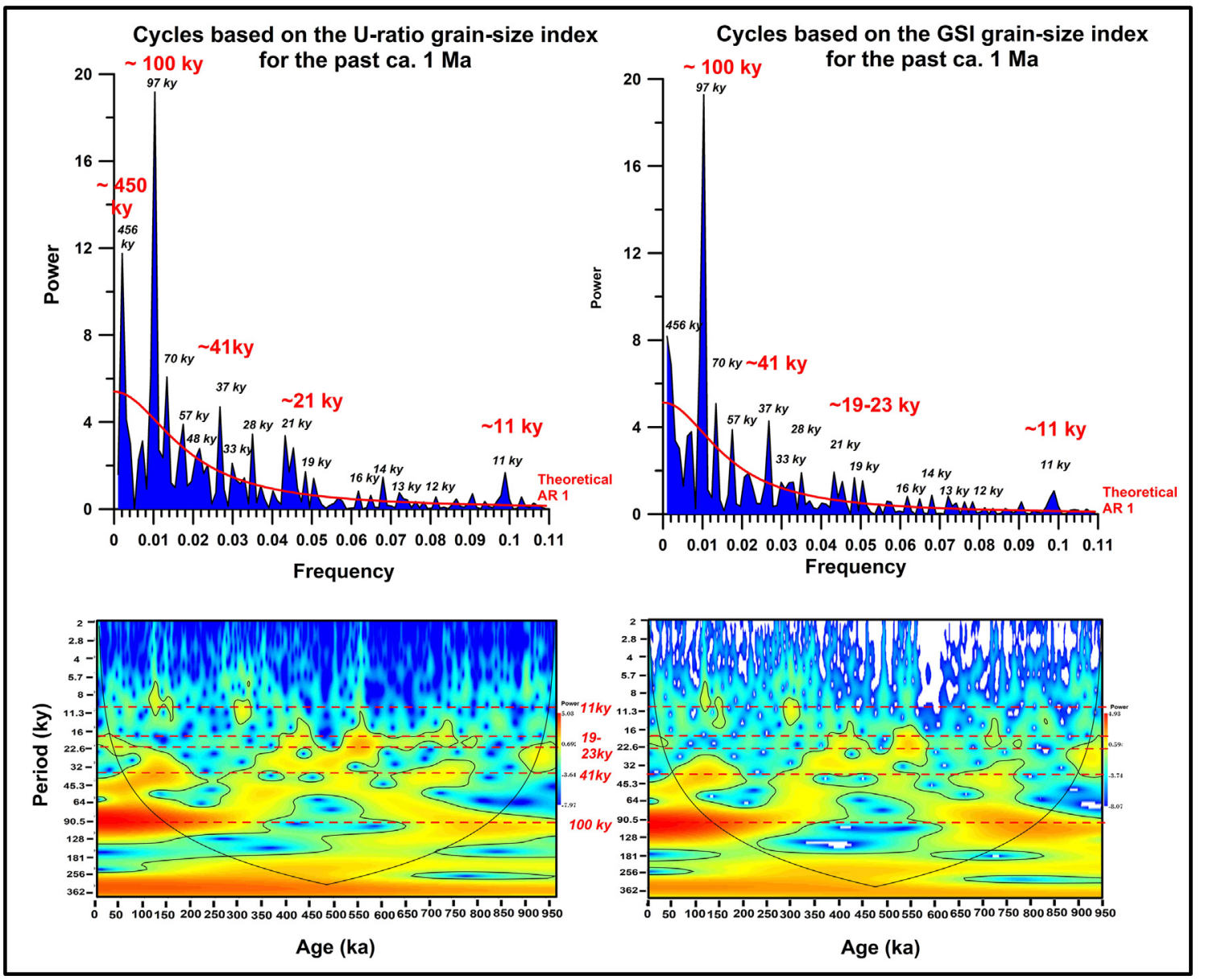

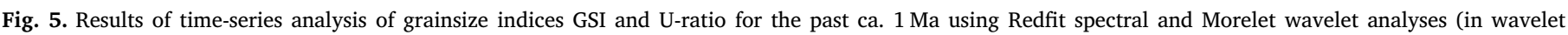
scalograms redder colors represent stronger cycles, solid lines indicate $95 \%$ confidence levels, dotted lines correspond to orbital periods).

noise as well. These cycles are generally weak throughout the entire sequence (Fig. 5). Low intensities below the $\mathrm{p}=0.05$ significance level is recorded between 1000 and $800,650-600,500-450,400-350$ as well as 350-250 ka (Fig. 5). The highest intensities are restricted to the past ca. $250 \mathrm{ky}$.

Statistically significant low power peaks occur at 28, 21, 19, 16, 14, 13,12 , and $11 \mathrm{ky}$, consistent with precession and half-precession. However, 21-ky cycles are present only between ca. 750 and $300 \mathrm{ka}$ with a peak strength between 650 and $550 \mathrm{ka}$. For the rest they are not well expressed (below the $\mathrm{p}=0.05$ significance level).

The non orbitally tuned GSI curve subjected to spectral analysis yielded similar cycles as the U-ratio (Fig. 5). The highest primary spectral peaks at periods of 456 and $97 \mathrm{ka}$ are eccentricity related. The peak with the highest power is also found at 97-ka. The 400-ky cycles are much weaker than in the U-ratio record. This is also true for the entire past $1 \mathrm{Ma}$ as seen at the bottom of the two wavelet scalograms of Fig. 5. Secondary peaks at 70 and $57 \mathrm{ky}$ may originate from the harmonics or interactions of the orbital cycles mentioned earlier (Lu et al., 2004; King, 1996). Additional statistically significant cyclicity is found at periods of 37,33 and $28 \mathrm{ky}$. These are partly obliquity related with rather low power. Variation in intensity of these cycles throughout the past $1 \mathrm{Ma}$ are comparable to the one described for the U-ratio.

Low power peaks occur at periods of $21,19,16,14,13$, and $11 \mathrm{ky}$ consistent with the (half) precession scale and are similar to the U-ratio cycles. The strength of these cycles displays the same temporal variation during the past ca. $1 \mathrm{Ma}$ as observed for the U-ratio index. When the two records are compared, it can be stated that longer period cycles are much stronger and persistent compared to smaller ones. In addition, $100-\mathrm{ky}$ cycles are the strongest during the past $300 \mathrm{ky}$.
The non-orbitally tuned fine sand/ fine silt curve yielded mainly similar, but somewhat different cycles observed for the U-ratio and GSI indices (Fig. 6). The highest primary spectral peaks here are also at 456, $97 \mathrm{ky}$. These are eccentricity related. But the highest frequency here is found at the dominant 450-ky cycles not 100-ky. The strong 400-ky cycles are constantly present with equal strength as seen on the bottom left wavelet scalogram of Fig. 6. Peaks at 70 and 57 ky also turn up as a result of interactions of the orbital cycles mentioned earlier (Lu et al., 2004; King, 1996). The 100-ky cycles are weaker between 900 and $300 \mathrm{ka}$ and experience a marked increase during the past $300 \mathrm{ka}$, as seen on both the lower left and upper right graphs of Fig. 6. However, in contrast to the previous two indices where these cycles are low intensity between 650 and $300 \mathrm{ka}$ (Mid-Brunhes transition), they are statistically significant throughout the entire sequence in the Fine sand/fine silt ratio record. Additional statistically significant cycles are found at 37, 33 , and $28 \mathrm{ky}$, similarly to the other records. These are partly obliquity related with rather low power, and are strong and significant during the Mid-Brunhes transition (650-500 ka) as well as during the past $200 \mathrm{ky}$. Low power peaks occur at 21, 19, 14, 13, 12, and 11 ky consistent with the (half) precession scale and display similar temporal variations in intensity to the GSI and U-ratio records; i.e. the strongest intensities are noted between 700 and $300 \mathrm{ka}$ with a maximum at $550 \mathrm{ka}$. The persistent presence of longer cycles of 400 and $100 \mathrm{kyr}$, rather than shorter ones, in our record at borehole U2A is in line with the conclusion of grain-size related time series analysis for the Xifeng and Louchoan loess/paleosol sequences of the Chinese loess plateau, where the records were not orbitally tuned (Lu et al., 2004). But there are subtle differences too.

In the grain-size record of the Xifeng loess paleosol sequence 


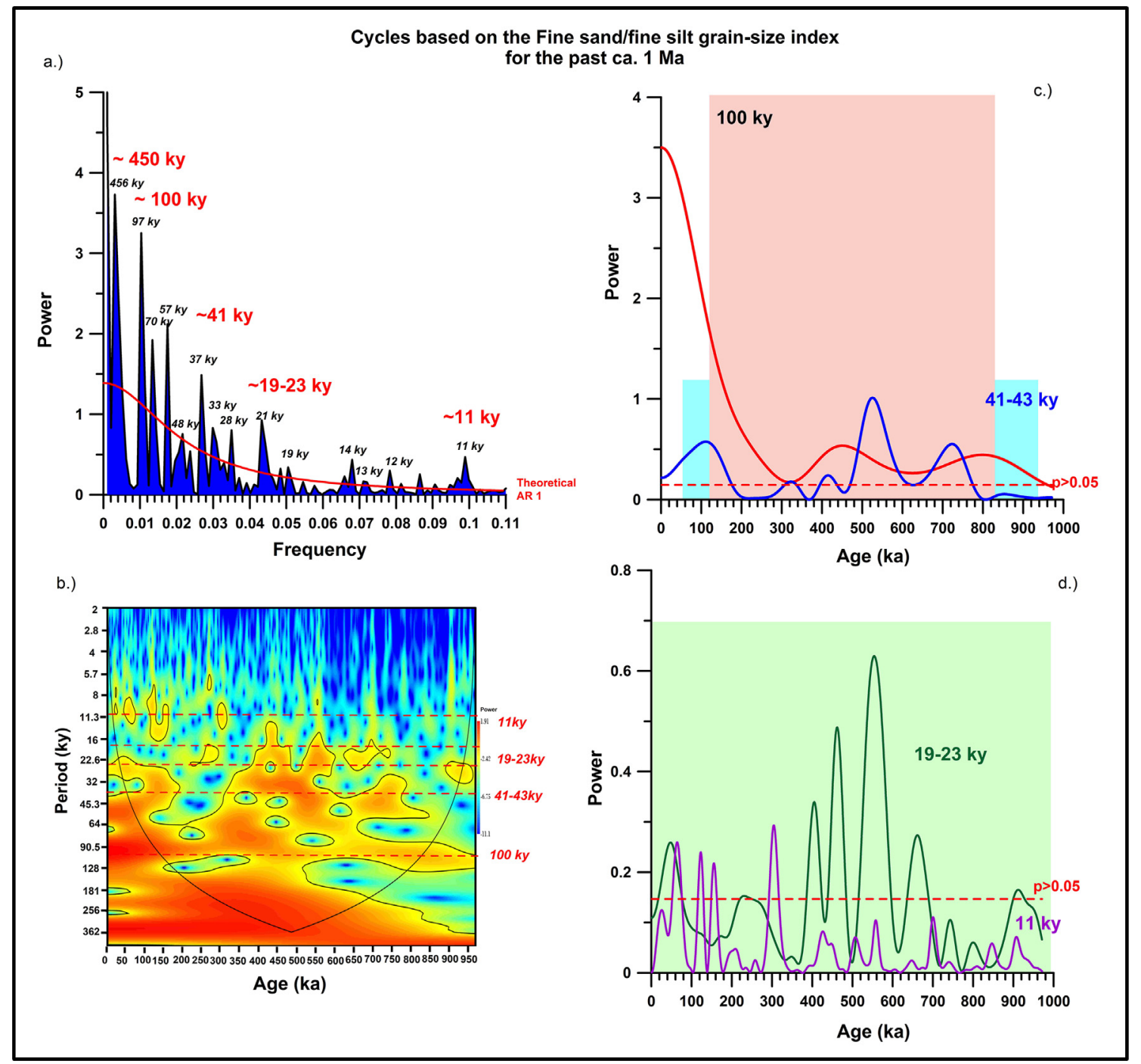

Fig.6. Results of time-series analysis of the Fine sand/fine silt index for the past ca. 1 Ma using Redfit spectral (a) and Morelet wavelet analyses (b) (redder colors represent stronger cycles, solid lines indicate $95 \%$ confidence levels, dotted lines correspond to orbital periods), c.,d.) variations in strength of the individual orbital cycles plotted from data extracted from results of the wavelet analysis along the line of orbital periods (shaded areas correspond to cone of influences for the individual cycles).

(Fig. 7), which is comparable to our record both in terms of sediment thickness and the position of the major age tie points for the past 900 kyr (Sümegi et al., 2018), 400-ky cycles are weaker than the 100-ky cycles (Lu et al., 2004). 100-ky cycles are strongest from $600 \mathrm{ka}$ onwards implying a higher sensitivity of the area to eccentricity related fluctuations. There are approximately 456, 250, 107, 48, 37, 33, 23, 21 , $19,15,13$ and 11 ky-cycles present as well. Some orbital driven cycles are weak and are not well-presented (Lu et al., 2004). In contrast to our records where 21-ky cycles are present between 700 and 300 ka with peak intensities around $550 \mathrm{ka}$ onwards, these are lacking in the Chinese Loess Plateau record of Xifeng. The lack of the hypothetically stronger cycles of 41 and 22 ky between 800 and 550 ka was interpreted as the outcome of unstable dust depositional processes on the one hand and the low temporal resolution of the LPS and the presence of non-orbital cycles on the other (Lu et al., 2004). These shorter cycles express the precession of the longitude of perihelion dominating the variability of solar input to higher latitudes driving the course of glacials-interglacials primarily (Rapp, 2012, Yin and Berger, 2010). Ice sheet buildup in general reacts to the 22-ky oscillations of solar intensity at high latitudes by growing when amplitude of oscillations is small and diminishing when amplitude of oscillations is high (Rapp, 2012). However, according to our current understanding, precessional oscillations seem to act as a signal carrier, whose amplitude is modulated by the variability of eccentricity (Rapp, 2012). This would explain the generally weak power of 21-ky cycles and the increased strength of eccentricity related cycles in our records. It is interesting to note that the period between 650 and $400 \mathrm{ka}$, when 21-ky cycles are strongest in our record (Fig. 6) coincide with maximum intensities of eccentricity in the global records (Rapp, 2012; Yin and Berger, 2010). Although the 100 -ky component is not as prominent in our record as after ca. $200 \mathrm{ka}$, the obvious overlap between the precessional and eccentricity cycles during this interval seemingly corroborate the importance of eccentricity in modulating the amplitude of precession in general (Rapp, 2012). However, a deviation from the mainstream global records may hint to the importance of regional forces in controlling these cycles too.

\section{Discussion}

\subsection{Grain-size variations and provenance of the deposited material}

Heavy mineral compositional analysis of loess and paleosol samples from the borehole Udvari 2a and the nearby Paks brickyard site exposing LPS of similar ages, revealed significant compositional differences (Thamó-Bozsó et al., 2013; Újvári et al., 2008, 2014). These must 


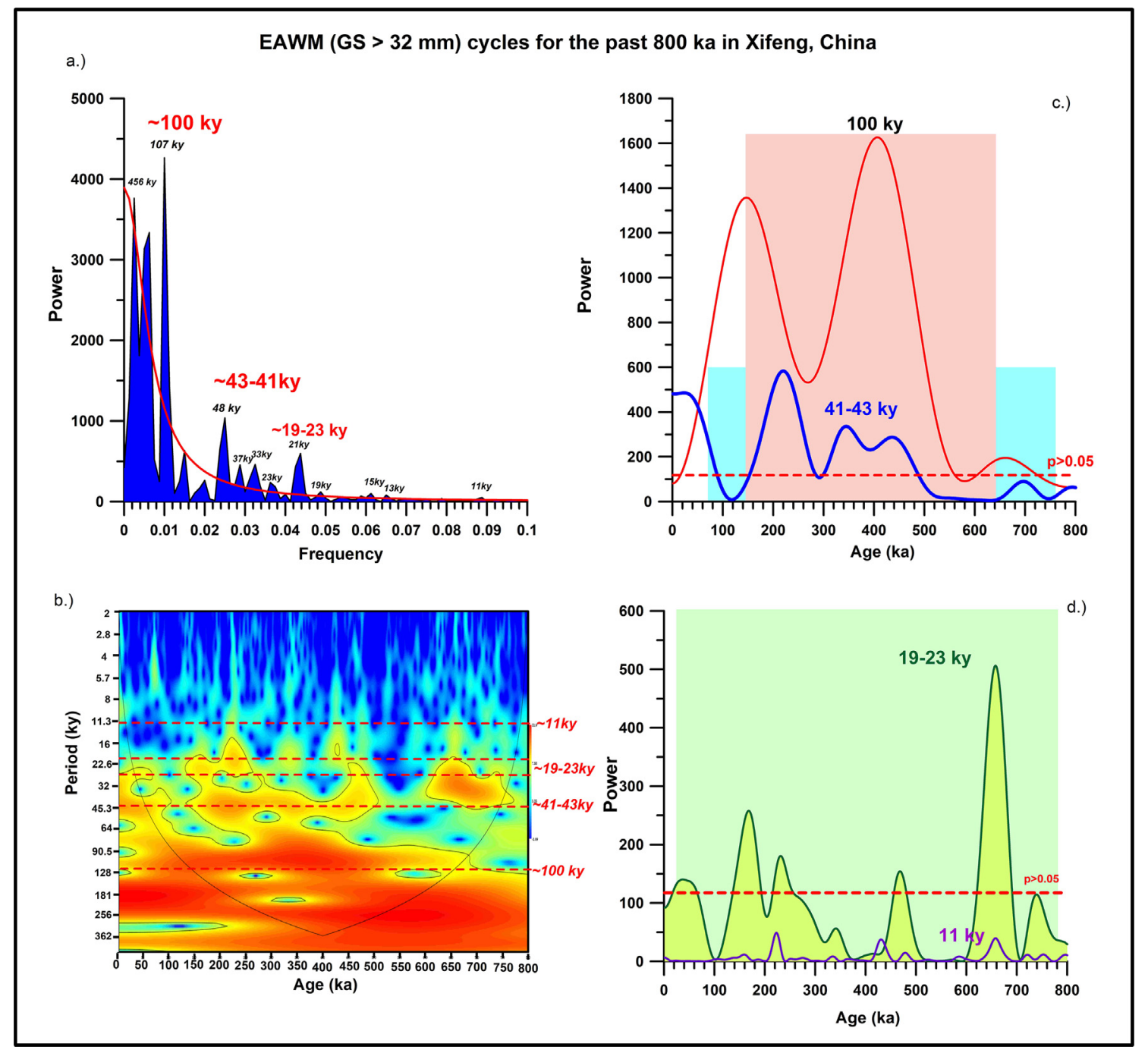

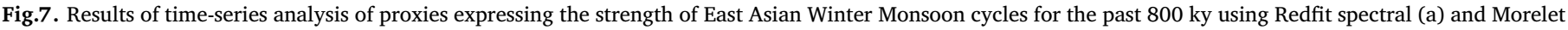

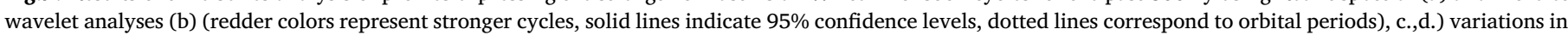

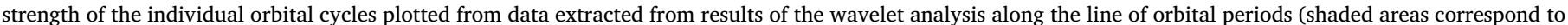
cone of influences for the individual cycles).

be relevant in the grainsize and leachate geochemistry record as well. In the case of Udvari 2a, we see a dominance of chlorite and biotite, just like in many other SW Transdanubian loess/paleosol sequences. However, it is quite different from the garnet-rich loess deposits of Paks ca. $20 \mathrm{~km}$ to the east of our site (Thamó-Bozsó et al., 2013). Both chlorite and biotite, as flaky minerals, have higher mobility than other heavy minerals. Thus, according to Thamó-Bozsó et al. (2013), these grains must be allochthonous; i.e. from the chlorite rich Late Miocene-Early Pliocene Lake Pannon deposits. These covered the Transdanubian MidMountains found $80-100 \mathrm{kms}$ northwest of our site from the Late Miocene (Fig. 8). Most of the western part of the Carpathian Basin underwent Plio-Quaternary uplift and denudation by the dominant northerly, northwesterly winds (SFig. 2) related to a structural inversion of former rift-related structures (Royden and Horváth, 1988; Tari and Horváth, 2006; Csillag et al., 2010; Ruszkiczay-Rüdiger et al., 2011, 2018a,b; Sebe et al., 2011). Knowing the hydrology of the denudated areas, fluvial erosion was negligible. Numerous blow-out valleys, deflation hollows, yardangs have been documented from the region of south and west of the Transdanubian Mid-Mountains (see Fig. 8), which were active from $1.5 \mathrm{Ma}$ as recorded by exposure ages (Csillag et al., 2010; Ruszkiczay-Rüdiger et al., 2011, 2018a,b; Sebe et al., 2011). Most deflation hollows, today filled by lakes (e.g. Lake
Balaton), are found on the lee side of the Transdanubian Mid-Mountains. As the modern climate is not favorable for wind abrasion, they must have formed under climate spells of the Pleistocene. So, these regions in fact could have been ideal sources of dust and sand for our site (Fig. 8). In the case of Paks the garnet-rich loess containing other minerals of metamorphic origin must derive from the Lower-Upper Pleistocene alluvial fan and floodplain of the Danube and its former branches found to the NE of the site (Fig. 8; Újvári et al., 2014; ThamóBozsó et al., 2013).

It is interesting to note that in our loess units corresponding to MIS6, MIS 10, MIS12, MIS16 and MIS 20 chlorite was present dominantly with percentages ranging between 56.3 and $78.6 \%$ (Fig. 9) while biotite was subordinate, ranging between 11.5 and $41.5 \%$ (Thamó-Bozsó et al., 2013). There is a strong negative correlation between the quantities of both minerals $\left(\mathrm{R}^{2}=-0.9283\right)$, indicating that periods of strong chlorite input were accompanied by reduced biotite input and vice versa. Nevertheless, the dominance of chlorite throughout the sequence was sustained.

If we compare variations in the concentration of the selected heavy minerals with those of selected grain-size parameters (coarse silt, sand) for the sampled periods of MIS6, MIS 10, MIS12, MIS16 and MIS 20, the emerging pattern in rather intriguing (Fig. 9). The general upward 


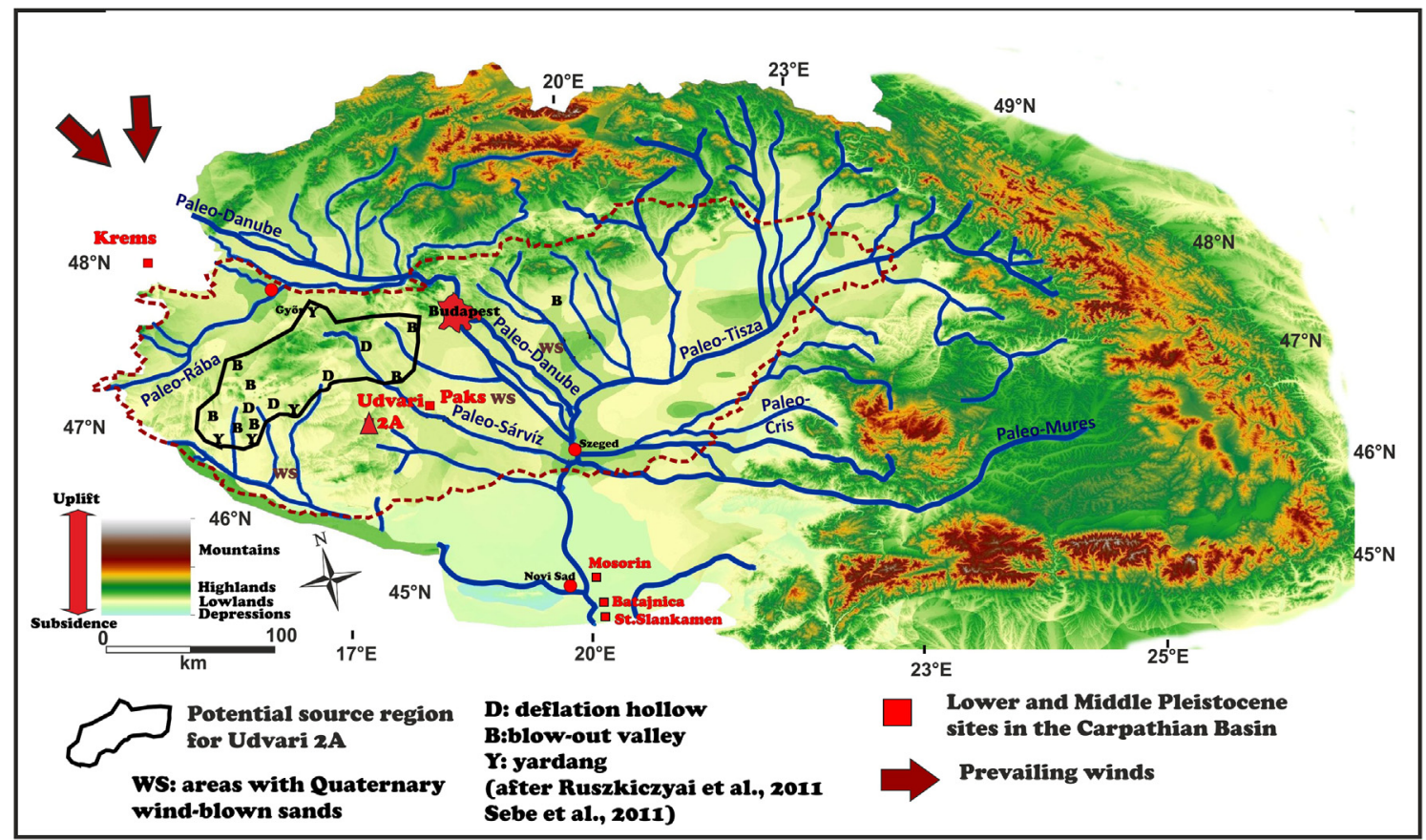

Fig.8. Paleogeography and paleohydrology of the Carpathian Basin from the Early Pleistocene with the most important LPS sites, potential source region for our study site Udvari 2A LPS and paleowind directions.

increase in the sand content from the bottom of U2L9 to the top of U2L5 is parallel with a gradual increase in biotite. The input of chlorite is relatively constant $(70-75 \%)$ from the sampled loess unit underlying the U2S9 pedocomplex (MIS 28-30) up to U2L6 (MIS 16). The reduction of the coarse silt content from U2L6 (MIS 16) to U2L5 (MIS 12) is accompanied by a ca. $10 \%$ decrease in chlorite. The stepwise heavy rise in the sand content during the same interval is parallel with a ca. $10 \%$ increase in biotite. A similar pattern is observed for the interval between the loess units of U2L3 (MIS 8) towards the bottom of U2L2 (MIS
6). In the U2L4 loess (MIS 10), there is a major ca. 30\% decrease in biotite compared to U2L5 (MIS 12). An increase of similar rate is noted in chlorite in this interval. This change is parallel with a steady rise in the coarse silt. So, during periods of higher sand input we see an increase in transported biotite and a similar rate of decrease in chlorite. Unfortunately, there is no information on the quartz content, which could help us identify the nature of the sand size particles. All in all, the trajectory of chlorite percentages seems to follow the pattern observed for the coarse silt fraction. While excursions noted for biotite seems to

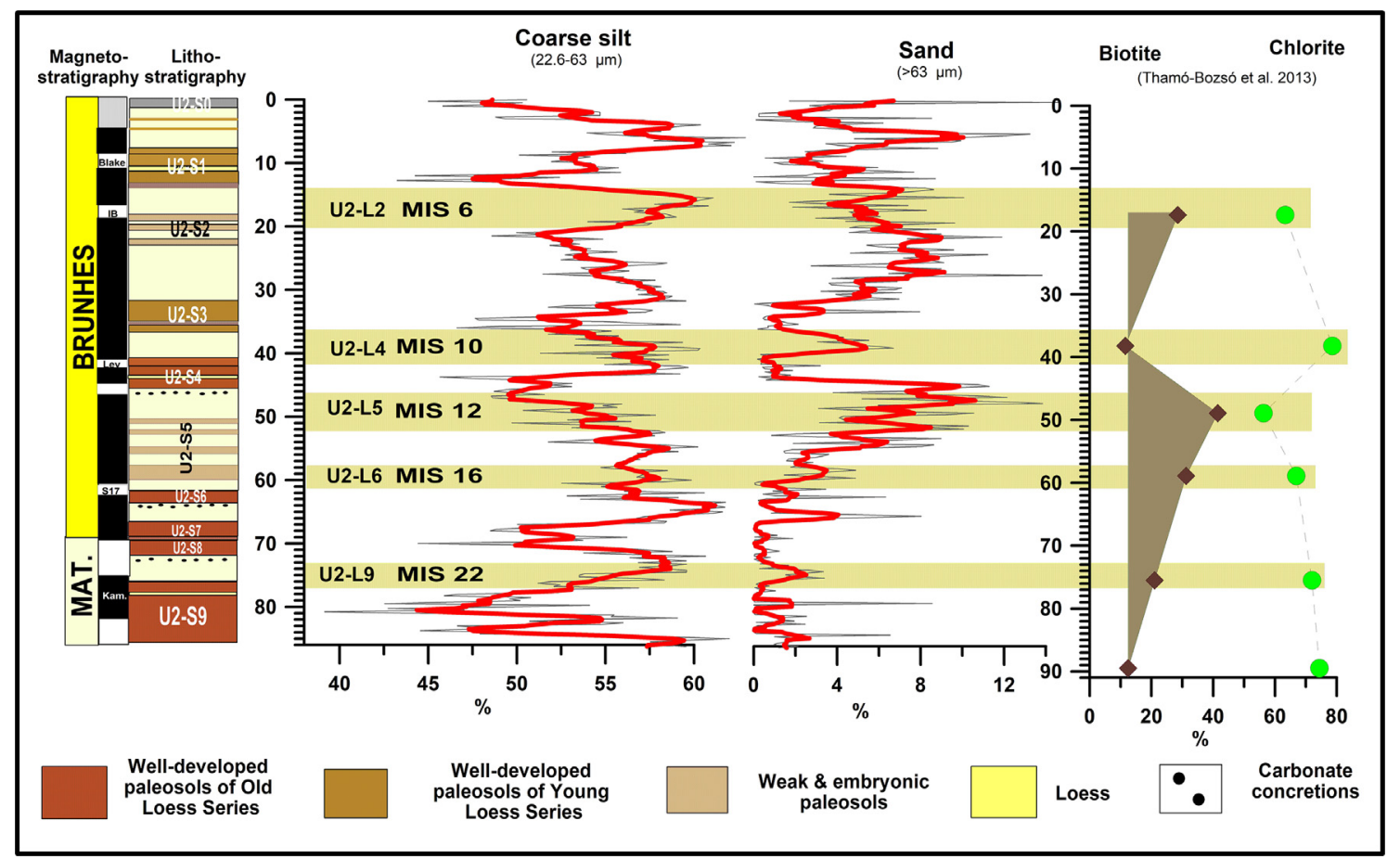

Fig.9. A comparison of coarse silt and sand content variations with selected heavy mineral concentrations from the literature (triangles represent sampling points for correlation with samples of heavy mineral analyses by Thamó-Bozsó et al. (2013); S1,2.etc. represents interglacial soils, L1,2..etc. corresponds to glacial loess). 
follow the trajectory of sand size particle changes.

The observed patterns highlight iterative changes in dust regime in the source area during the different glacials of the past $1 \mathrm{Ma}$. So, the larger input of sand and an increase in biotite with a relatively constant input of chlorite from MIS 16 to MIS 12 and MIS 10 to MIS 8 may indicate the inclusion of new source areas or some changes in the lithology of the bedrock by increased wind abrasion. This is feasible either in periods of higher wind velocities, when wind speed was strong enough to put newer source areas under erosion while maintaining a relatively constant flux from the other distant sources located at 80-100 $\mathrm{kms}$ to the NW. Another possibility could be the displacement of the source areas closer to the sink areas as has been noted by studies at the Chinese Loess Plateau (Stevens et al., 2018). These studies found strong teleconnections between the proximity of source areas and increases in the concentration of coarse grains as well as potential erosional hiatuses in one of the key Quaternary stratigraphical records of the Chinese Loess Plateau (Stevens et al., 2018).

As the deflation hollows, blow-out depressions and yardangs are located at a fairly constant distance from our site (Fig. 8), this latter factor must have been less influential in our case. Furthermore, studies documenting changes in wind abrasion in our source areas highlighted a slight acceleration of denudation rates during the Pleistocene, which was interpreted as an outcome of the development stronger winds with the onset of longer glacials (Ruszkiczay-Rüdiger et al., 2011, 2018a,b; Sebe et al., 2011). Denudation rates for the period of the Lower Pleistocene (1.56 Ma-870 Ka) in the Transdanubian Mid-Mountains were varying in the source areas between 24 and $66 \mathrm{~m} / \mathrm{Ma}$ with an average of $40 \mathrm{~m} / \mathrm{Ma}$ (Ruszkiczay-Rüdiger et al., 2011). There was a marked increase from $800 \mathrm{ka}$ to $280 \mathrm{ka}$ to an average rate of $53 \mathrm{~m} / \mathrm{Ma}$ followed by a similar rate of $52 \mathrm{~m} / \mathrm{Ma}$ until the Holocene. Some more open sites (Tapolca Basin) on the western margin of the Transdanubian MidMountains have experienced an even larger erosional rate (average of $75 \mathrm{~m} / \mathrm{Ma}$ ) from the Middle Pleistocene (Ruszkiczay-Rüdiger et al., 2011). This would mean the removal of almost $1 \mathrm{~m}$ of rock on average for a period of $10 \mathrm{ky}$. Unfortunately, there is no higher resolution data available for the denudation of the source area, which could be compared to our grain-size record.

\subsection{Comparison with other regional and extra regional records}

Spectral analysis of the orbitally tuned stacked MS records of northern Serbia (Marković et al., 2012; Basarin et al., 2014) using Lomb periodogram revealed the presence of $256,97,66,38,35,24,22$ and 19-ky cycles with a clear dominance of the eccentricity and obliquity related cycles. The 400-ky cycle was not found in previous studies, in contrast to our records. In addition, as the significance lines related to white noise of $\mathrm{p}<0.05$ and $\mathrm{p}<0.01$ are not reported, one cannot be certain which peaks are significant and prominent from the obliquity and possibly precession related cycles. Based on the general shape of the spectrogram one would assume the lack of significant precession related cycles, but this assumption is only tentative without proper data on white noise values.

Overall fluctuations in mass accumulation rates at our site seem to be well-correlated with grain-size index value changes (Fig. 10, top). So, the observed GS fluctuations are reliable indicators of dust flux variations from the source to the sink areas on a longer term. There is an overall increase in all GS indices as well as MAR from 1 Ma to ca $750 \mathrm{ka}$ (MIS 18) (Figs. 10 and 11) with minor fluctuations. During the referred interval a similar overall expansion of the Eurasian ice sheets is noted (Hoddel et al., 2008; Fig. 10) although its magnitude is below that of the glacials after the 640-ka transition. There is a general decrease in eccentricity reaching a minimum at MIS 18 (Fig. 11) too. Variations in the strength of the East Asian Winter Monsoon seen from the Chinese Loess Plateau records has a different trajectory with a major rise until MIS 22 followed by a steady decrease until MIS 18 (Fig. 11). The same pattern characterizes the thermocline sea temperature records from the northwest Iberian margin (Bahr et al., 2018; Fig. 11) implying that all records responded to a common climatic forcing. The noted sudden increase from MIS 24 to MIS 22 followed by a decrease until MIS 20 is present in our grain-size record as well. However, from MIS 20 to MIS 18 (Figs. 10 and 11) there is a pronounced increase in our records contrasting all other referred extra regional records. This period corresponds to the second phase of the Mid-Pleistocene Transition when 100-ka glacial/interglacial cycles emerged from 1.25 Ma onwards (e.g. Lisiecki and Raymo, 2005; McClymont et al., 2008, 2013; Hao et al., 2012; Bahr et al., 2018). This shift from 41-ka to 100-ka periodicity was seen on the wavelet transform of our GS proxies with the appearance of moderately strong 100-ky cyles in this period as well (Figs. 5 and 6). In the global marine (Lisiecki and Raymo, 2005; Raymo et al., 2006) and European terrestrial records (Tzedakis et al., 2006), MIS 20 and 18 are weak glaciations. This is also seen in the Chinese Loess Plateau grainsize and magnetic susceptibility records, where Hao et al. (2012) pointed to a delayed build-up of Arctic ice sheets during insolation and eccentricity minima (Fig. 11) following the interglacials of MIS 21 and MIS 19, respectively. MIS 20 is characterized by lower GSI and D50 values and minimal sand content in our record (Figs. 3 and 10). According to the interpretation of Hao et al. (2012), the persistence of a weak East Asian Winter Monsoon (EAWM) and a weak Siberian High (SIH) suppresses ice and snow accumulation at high northern latitudes. A weak SIH generally leads to the contraction of the polar front and the northward displacement of Mediterranean cyclones towards our site, leading to relatively mild falls and winters but with increased precipitation. This is also seen in the somewhat higher thermocline sea temperature records from the northwest Iberian margin compared to MIS 22-24 glacials (Bahr et al., 2018; Fig. 11).

The peak at ca. $750 \mathrm{ka}$ (MIS 18) in our GSI record (Figs. 10 and 11) coincides with the first minimum of eccentricity and summer solar input to the $\mathrm{NH}$ Arctic region during the past $1 \mathrm{Ma}$ (Fig. 11). This glacial saw weakened the EAWM (Fig. 11), like MIS 20, pointing to a weakened $\mathrm{SIH}$ and northward shift of the polar front in Siberia. Eurasian ice sheet expansion seems to be constant or slightly higher than at MIS 22 (Hoddel et al., 2008; Hoddel and Channell, 2016; Fig. 11). However, thermocline temperatures at the Iberian Margin are high around 760-740 ka (Fig. 11). It indicates a southward displacement of the subpolar front and adjacent cyclone belt in the Northern Atlantic region in contrast to Siberia (Bahr et al., 2018), which propagates the transport of warmer air to SE Europe. The transport of warmer, humid air facilitates the growth of Alpine glaciers surrounding the Carpathian Basin. It also contributes to the relative sustainment of forests in Greece, where AP ratios are higher than during any other succeeding glacials, except MIS 14. Due to the low topography of the surrounding hills and mountains in the Carpathian Basin during the early Pleistocene (Fig. 8), the proximity of ice sheets must have significantly influenced the wind regime in the area. Modern zonal westerlies enter the basin through major gaps from the west and east, whose position is controlled by the height of the Carpathians and the Alps. Based on geochemical data the dominance of northerly, northwesterly katabatic winds was propagated for the periglacial Carpathian Basin during the major glaciations (Buggle et al., 2009). Winds speed in the Carpathian Basin during the Pleistocene is the result of the interplay of climate and topography. The modern surface wind system of the western part of the Carpathian Basin, with an NNW orientation (Fig. S2), is relatively stable due to the topographic control by the dominant landforms of parallel valleys with a NW-SE orientation in the Transdanubian Mid-Mountains. Airflow directions recorded by Pleistocene and Holocene landforms of the area (wind striations on dated surfaces) also agree with the postulated wind fields during much of the Pleistocene (Fig. S2; National Atlas of Hungary 2018; Ruszkiczay-Rüdiger et al., 2011; Sebe et al., 2011). Increased cyclonic activity from the west as mentioned in connection with paleoclimate records from the NW margin of the Iberian Peninsula for the MIS 18 glacial must have propagated the formation of stronger circulation and higher wind speeds. In periglacial areas, the increased 


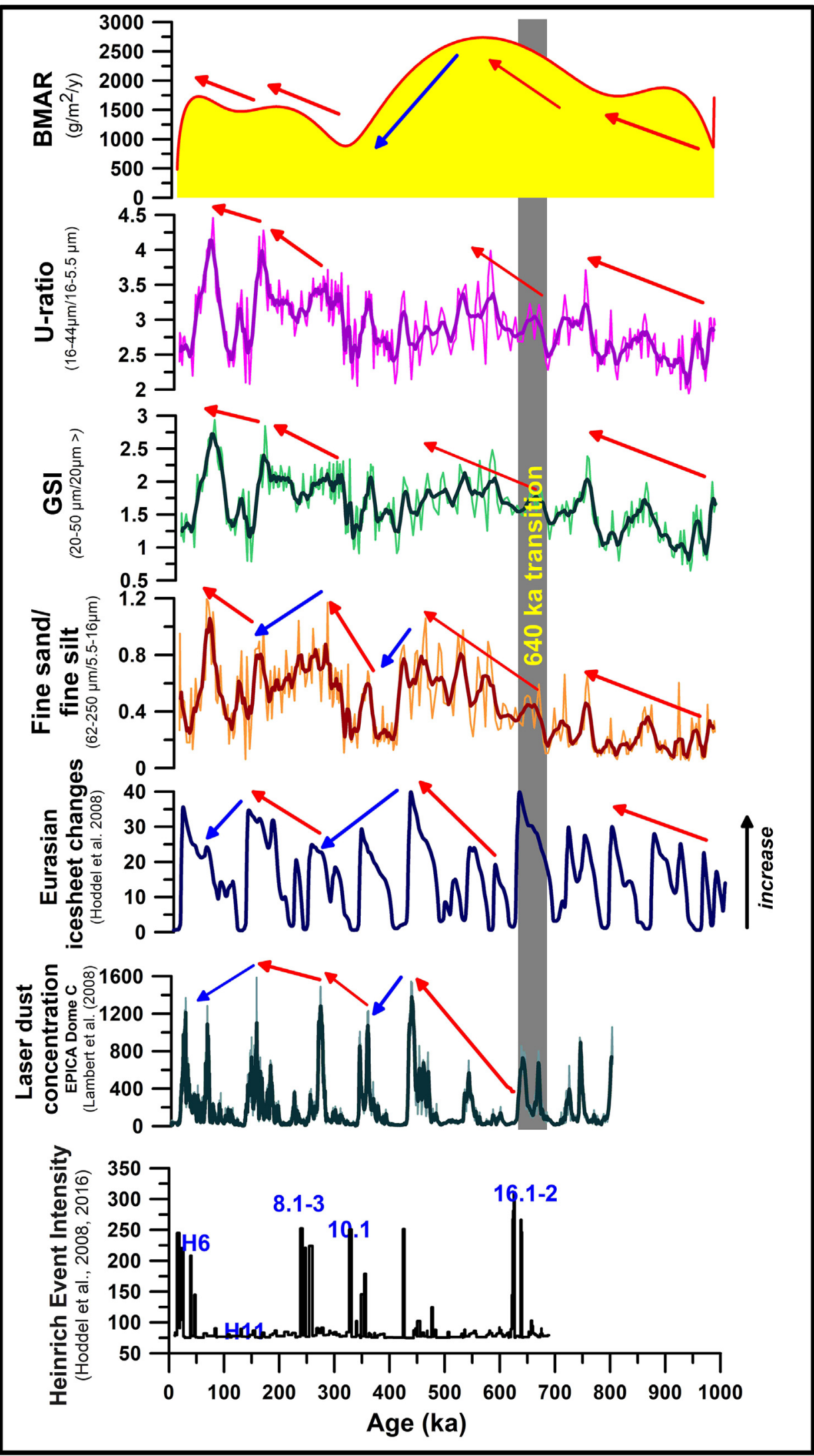

Fig.10. Comparison of the variation of grain-size indices with calculated mass accumulation rates at our site with other extra regional records of Eurasian ice-sheet dynamics (Hoddel et al., 2008, Obrochta et al., 2014), dust flux to EPICA Dome C (Lambert et al., 2008) and intensity of ice-rafted debris (IRD) transport to the subpolar North Atlantic (Hoddel et al., 2008, 2016) for the past 1 Ma. (H6, H11, 8.1-3, 10.1, 16.1-2 correspond to Heinrich and Heinrich-like events). 


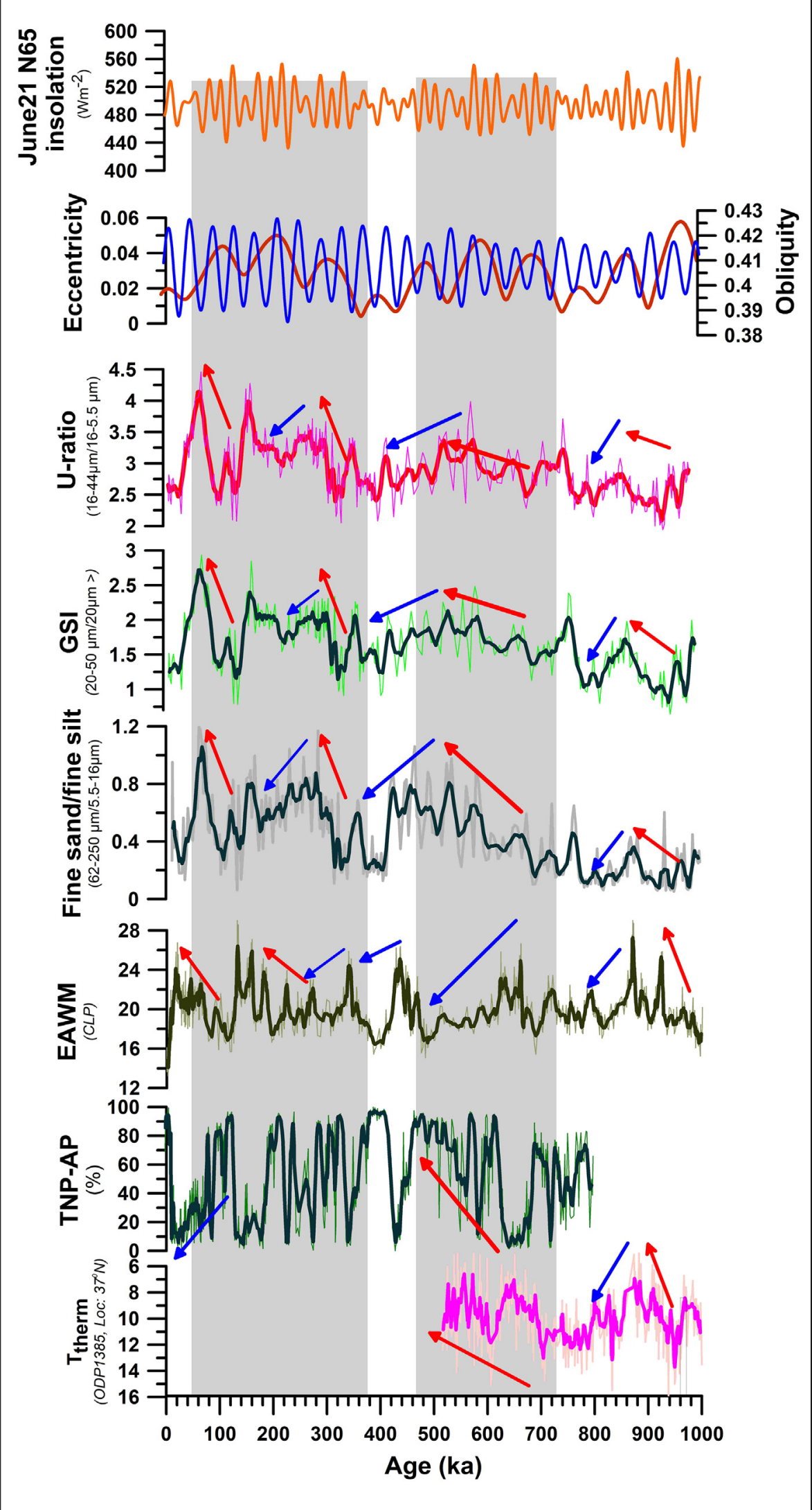

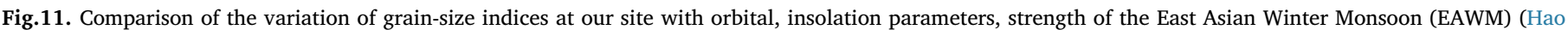

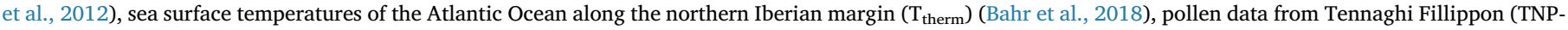
AP) (Tzedakis et al., 2006) for the past $1 \mathrm{Ma}$. 
pressure and temperature gradients created by the ice mass must have further enhanced air circulation (Isarin et al., 1997; van Huissteden and Pollard, 2003). The resulting stronger winds in the area must have been further accelerated by the channeling effect of the topography in Western Hungary creating geomorphologically more effective winds producing higher wind denudation in the previously mentioned source areas NW of our site (Ruszkiczay-Rüdiger et al., 2011; Sebe et al., 2011). This is also seen in the formerly mentioned stepwise increase of calculated denudation rates from an average of $40 \mathrm{~m} / \mathrm{Ma}$ to $53 \mathrm{~m} / \mathrm{Ma}$ from 780 ka (Ruszkiczay-Rüdiger et al., 2011; Sebe et al., 2011).

Thus, the seen grain-size increase in our records must reflect a climatic response to the growth and proximity of the Alpine glaciers on the one hand as well as the southward displacement of the westerlies in the Northern Atlantic during the MIS 18 glacial. These factors clearly explain the differential behavior of our study area from the far east and the rest of Europe.

The 640-ka transition marks the emergence of quasiperiodic 100 -ky cycles (Hoddel et al., 2008; Hoddel and Channell, 2016) with a pronounced shift in the style and intensity of glacial-interglacial cycles and IRD delivery to the subpolar North Atlantic seen also in the emergence of the first Heinrich-like events at MIS16 (Fig. 10) and lengthening of the glacial cycle (Hoddel et al., 2008; Hoddel and Channell, 2016). From this transition interval all our GS records undergo a rapid increase till ca. $450 \mathrm{ka}$. A similar increase is visible in our MAR with a peak between ca. 650 and $450 \mathrm{ka}$ (Fig. 10). Dust concentrations in the Antarctic ice core of EPICA Dome C display a similar major rise compared to the dust flux of the previous glacials marking a general increase in global dust load (Fig. 10). There is a gradual weakening of the EAWM and the SIH (Fig. 11) again implying a northward displacement of the polar front in Siberia and a differential response of the Chinese Loess Plateau during the mentioned interval. A gradual decrease in thermocline temperatures along the Iberian margin (Bahr et al., 2018) as well as AP percentages at Tennaghi Phillipon (Fig. 11) indicate a significant contraction of the polar front in the North Atlantic resulting in a northern displacement of the westerly cyclone belt resulting in an increased aridity in SE Europe as well as the Carpathian Basin from MIS 16 to MIS 12 propagating higher denudation of the source areas.

MIS 12 is another extensive glaciation (Head and Gibbard, 2005; Van Gijssel, 2006; Gibbard and Cohen, 2008; Marković et al., 2015), with the first glaciers developing in the Mediterranean mountains (Hughes et al., 2006, 2010, 2013; Kuhleman et al., 2008; Marković et al., 2015). It is also the time when the Eurasian Ice Sheet reached the NE foothills of the Carpathians. The strengthening of the EAWM and SIH also indicates a rapid build-up of Arctic ice sheets during a period of moderate insolation (Hao et al., 2012). After an interval of low intensity MIS 12 also marks the first prominent peak of IRD transport to the North Atlantic after MIS 16. Rapidly increasing high sand content, the highest among the period from MIS 22 to MIS 12, and fine sand/fine silt ratios, D50 values towards MIS 12 imply the strengthening of NW and $\mathrm{NE}$ winds during this glacial in line with the documented expansion of the European Ice Sheet (Fig. 10) and other global records marking a rapid built-up of northern ice sheets (Hao et al., 2012). The appearance of the first major peak in dust concentrations of Antarctic also signifies the importance of increased airflow. The SE European forest records also document a rapid and strong drop in woodland cover (Fig. 11). This is the time of highest MAR at our site (Fig. 10). The major peak in the center of the glacial correlates well with the 12.1 Heinrich-like event (Hoddel et al., 2008; Obrochta et al., 2014).

MIS 10 is characterized by a weak growth of continental ice (Kukla, 1975), reduced ice extent in marine and ice core records. MIS 10 is also characterized by a delayed build-up of Arctic ice sheets during another insolation minimum leading to weaker EAWM and SIH (Hao et al., 2012) than during MIS 12. This is seen in a smaller peak in our GSI records compared to preceding and successive glacials (Figs. 10 and 11). Also, the smallest MAR are documented here in our record (Fig. 10).
Although MIS 8 was characterized by a rapid strengthening of EAWM and SIH, as well as a quick buildup of Arctic ice sheets following the MIS 9 interglacial (Hao et al., 2012), much of the glacial is prevailed by weak EAWM indicating a possible northward displacement of the polar front in Siberia. The expansion of the Eurasian ice-sheet is much lower than during MIS 12 or even MIS 10.

Our recorded grain-size values however show a rapid increase after $300 \mathrm{ka}$. (Fig. 10). It is also the first time, when increasing continentality in the basin appears after the surrounding mountains reached a critical height (Buggle et al., 2013). Clay mineral properties and inferred soil development taken from the work of Földvári and Kovács-Pálffy (2002) tend to co-vary with our grain-size record with minor discrepancies attributable to the different resolution of sampling. Parallel with the upward increase in all grain-size indices there is a gradual decrease in montmorillonite content as well as the general water content of clay minerals. These changes are in line with global records showing a gradual upward increase in dust flux parallel with the reduced duration of full interglacial conditions following the Mid-Brunhes transition around 400 ka (Hovan et al., 1991; Lüthi et al., 2008; Lambert et al., 2012; Banerjee and Jackson, 1996; Rapp, 2012). On the one hand, the gradual upward weakening of soil development may be the outcome of increasing aridity and low pedogenetic clay formation from $400 \mathrm{ka}$. Increasing aridity was noted from $400 \mathrm{ka}$ for several sites in the Middleand Lower Danube Basins (Marković et al., 2009; Buggle et al., 2009, 2010, 2013; Obrecht et al., 2016; Zeeden et al., 2016, Zöller, 2010). However, as noted earlier, the upward decrease in the referred clay mineral content is accompanied clearly by increasing sand and coarse silt content which may indicate increased physical weathering in the source areas too. The importance of physical weathering vs. aridity was postulated for the same interval in case of the nearby Paks profile as well (Újvári et al. 2014). However, the two processes are not completely exclusive. Higher aridity in the source areas might have triggered higher erosion by lowering the groundwater table enabling the denudation of formerly more resistant surfaces. This could have contributed to the transportation of larger size particles to our site. Zeeden et al. (2016) reports an increased sand input to the Semlac LPS profile, found SE of the eastern Hungarian border, during the last phase of MIS 9. This phenomenon was interpreted as an outcome of stronger winds or the proximity of the Mures river as a potential source area. However, as it is recorded in other Hungarian sites too it must be a regional phenomenon. Consideration of various biotic proxies (mollusks, alkanes, phytoliths) in future work may help identifying the role of humidity changes in influencing regional dust flux and loess formation.

During MIS6 the advances of Eurasian ice margins were significantly more southerly (Fig. 10) than during the last glacial period (Weichselian and equivalents; Head and Gibbard, 2005; Hoddel et al., 2008; Hoddel and Channell, 2016). This is further justified by the peaks indicating a strong EAWM and Siberian High (Fig. 11) compared to the other preceding glacials. One of the highest D50, sand content as well as GSI values in our record refer to a potential strengthening of NW winds carrying larger particles to the site. This is also the first glacial, when a peak after the low MAR of the interglacial MIS 9 is reached during a time of decreasing eccentricity (Figs. 10 and 11).

After the last interglacial global ice volume continually increased culminating in the glacials of MIS 4 and MIS 2 (Lambeck and Chappell, 2001; Fitzsimmons et al., 2012). The greatest thickness of the Danubian loess deposits formed during this period (Marković et al., 2015). Although MIS 4 is characterized by a rapid but moderate increase in EAWM and SIH (Hao et al., 2012), it is defined by the increased accumulation of loess in response to colder and drier conditions and plentiful sediment supply. This is also the period when the second peak of MAR appears after MIS 9 (Fig. 10). An increase in wind strength was also noted during the analysis of some Vojvodinian profiles (Marković et al., 2009; Fitzsimmons et al., 2012). Novothny et al. (2011) also reported that MIS 4 was colder and drier with an increased wind activity from a site near Süttő NW Hungary. The period corresponds to a 
cold phase recorded in North Atlantic marine records with Heinrich events 4-6 (Fig. 10) and suggest climatic teleconnections (Fitzsimmons et al., 2012; Stevens et al., 2011). Our record is also characterized by the highest peaks of GSI values and sand content of the past $800 \mathrm{ky}$.

\section{Conclusions}

Results of time series analyses of the three grain-size indices at our site revealed that the $100 \mathrm{kyr}$ cycles are constantly present throughout the past $900 \mathrm{ky}$. The stepwise change in the climate corresponding to the second phase of the Mid-Pleistocene Transition is also recorded. The $100 \mathrm{kyr}$ cycles are moderately strong between 900 and $650 \mathrm{ky}$. These cycles are weaker between 360 and 650 ky corresponding to the MidBrunhes transition. It also falls into an interval when the development of a $400 \mathrm{kyr}$ minimum of insolation variability is observed (Laskar et al., 2004; Rapp, 2012; Hao et al., 2012). Shorter cycles are also present but less persistent. Precessional cycles are strongest between 650 and $400 \mathrm{ky}$, when the eccentricity component is not as pronounced as in the younger part of the profile (after $200 \mathrm{ky}$ ). The amplitude of precessional cycles is generally understood to be modulated by variations in eccentricity (Rapp, 2012, Laskar et al., 2004). This deviation in our record may hint to the importance of regional forces in controlling these cycles too.

The strongest development of the 100-kyr cycles during the past $360-400 \mathrm{ky}$ is in accordance with the pattern observed in other global records as well (Berger and Wefer, 2003; EPICA members, 2004; Yin and Berger, 2010). This is also the time when the emergence of higher continentality contributes to climatic evolution of the area.

Comparison of our grain-size record with other coeval regional and extra regional paleoclimate records for the past 1 Ma revealed strong teleconnections with the expansions of the northern hemisphere ice sheets, the North Atlantic, the western Mediterranean margin and SE Europe. Contrasting trends with the Chinese Loess Plateau in certain periods reflect the greater influence of the Northern Atlantic region on the Quaternary paleoclimate of our area propagating the rise and vanishing of the icefields in the Alps and Northern Europe. The proximity and expansion of these ice-sheets in the Alps, the Mediterranean and the Eastern Carpathians (Hughes et al., 2006, 2010, 2013; Kuhleman et al., 2008; Marković et al., 2015) was all controlled dominantly by the expansion and contraction of the polar front in the North Atlantic besides other global climate forcings propagating the southward and northward displacement of warm and humid airflow towards the heart of the continent. They had a clear impact on the strength of the dominant wind fields resulting in increased wind abrasion in the source areas found in the NW Middle Danube Basin. Changes in intensities of tectonic uplift may have had an impact on denudation intensities of the source areas. These are hard to capture and quantify though. Winds were further accelerated by the channeling effect of the evolving Quaternary topography of the basin and source area. These forces were most pronounced at times when the mountains surrounding the Carpathian Basin were relatively low preceding $400 \mathrm{ka}$. Thus besides fluctuations in major climate forcings controlling solar radiation and the intensity of glacial-interglacial cycles during the past $1 \mathrm{Ma}$, these regional factors significantly affected the evolution of the landscape in the Carpathian Basin as seen in the transport and accumulation of coarse grains and largest dust flux to our site from $700 \mathrm{ka}$ to $450 \mathrm{ka}$. After $400 \mathrm{ka}$ there is another marked upward increase in grain-size distributions during the glacials which could result from increasing continentality of the area as the surrounding mountain belt reached a critical height. This shift is noted at other Hungarian (Újvári et al., 2014), Romanian (Zeeden et al., 2016) and Vojvodinian sites too (Marković et al., 2009; Fitzsimmons et al., 2012). Increasing continentality must have propagated increased aridity in the source areas resulting in a significant drop in the groundwater table and intensified erosion of formerly relatively stable surfaces.

\section{Acknowledgements}

Two anonymous reviewers and Jan-Berend Stuut are thanked for their useful comments helping to improve the language and scientific content of the paper. Research has been carried out within the framework of University of Szeged, Interdisciplinary Excellence Centre, Institute of Geography and Earth Sciences, Long Environmental Changes Research Team. Support of the Ministry of Human Capacities, Hungary grant 20391-3/2018/FEKUSTRAT and GINOP-2.3.2-15-201600009 'ICER' is acknowledged.

\section{Appendix A. Supplementary data}

Supplementary data to this article can be found online at https:// doi.org/10.1016/j.aeolia.2019.07.002.

\section{References}

Ádám, L., Marosi, S., Szilárd, J., 1981. Magyarország tájföldrajza IV. A Dunántúlidombság (Dél-Dunántúl). (Landscape geography of Hungary Vol.4. The Transdanubian Hills (South Transdanubia),. Akadémiai Kiadó, Budapest (in Hungarian).

Alcántara-Carrió, J., Fernández-Bastero, S., Alonso, I., 2010. Source area determination of aeolian sediments at Jandia Isthmus (Fuerteventura, Canary Islands). J. Marine Syst. Models Observations Mar. Syst. 80, 219-234.

Antoine, P., Rousseau, D.D., Zöller, L., Lang, A., Munaut, A.V., Hatté, C., Fontugne, M., 2001. High-resolution record of the last inter-glacial-glacial cycle in the Nussloch loess-palaeosol sequences. Germany Quaternary International, Upper Rhine Area 76-77 211-229.

P. Antoine Hatté Rousseau C., Zöller, L., Lang, A., Fontugne, M., Moine, O., Événements éoliens rapides en contexte loessique: l'exemple de la séquence du Pléniglaciaire supérieur weichselien de Nussloch (Vallée du Rhin-Allemagne) Quaternaire 132002 199-208.

Antoine, P., Rousseau, D.D., Moine, O., Kunesch, S., Hatté, C., Lang, A., Zöller, L., 2009a. Evidence of rapid and cyclic eolian deposition during the Last Glacial in European loess series (Loess events): the high-resolution records from Nussloch (Germany). Quat. Sci. Rev. 28, 2955-2973.

Antoine, P., Rousseau, D.G., Degeai, J.P., Moine, O., Lagroix, F., Kreutzer, S., Fuchs, M., Hatté, C., Gauthier, C., Svoboda, J., Lisa, L., 2013. High-resolution record of the environmental response to climatic variations during the Last Interglacial-Glacial cycle in Central Europe: the loess-palaeosol sequence of Dolní Vestonice (Czech Republic). Quat. Sci. Rev. 148, 228-258.

Antoine, P., Rousseau, D.D., Fuchs, M., Hatté, C., Marković, S.B., Jovanovic, M., Gaudenyi, T., Moine, O., Rossignol, J., 2009b. High-resolution record of the last climatic cycle in the southern Carpathian Basin at Surduk (Vojvodina, Serbia). Quat. Int. 198, 19-36.

Bahr, A., Kaboth, S., Hodell, D., Zeeden, C., Fiebig, J., Friedrich, O., 2018. Oceanic heat pulses fueling moisture transport towards continental Europe across the midPleistocene transition. Quat. Sci. Rev. 179, 48-58. https://doi.org/10.1016/j. quascirev.2017.11.009.

Banerjee, S.K., Jackson, M., 1996. Wind-borne dust holds clues to early climate. Earth Space 8, 12-14.

Basarin, B., Buggle, B., Hambach, U., Marković, S.B., O'Hara-Dhand, K., Kovačević, A., Stevens, T., Guo, Z.T., Lukić, T., 2014. Time-scale and astronomical forcing of Serbian loess-paleosol sequences. Glob. Planet. Chang. 122, 89-106.

Berger, W.H., Wefer, G., 2003. On the Dynamics of the Ice Ages: Stage-11 Paradox, MidBrunhes Climate Shift, and 100-kyr CycleEarth's Climate and Orbital Eccentricity: the Marine Isotope Stage 11 Question. Geophysical Monograph, American Geophysical Union, Washington, DC, pp. 41-59.

Biswas, D.K., Hyodo, M., Taniguchi, Y., Kaneko, M., Katoh, S., Sato, H., Kinugasa, Y. Mizuno, K., 1999. Magnetostratigraphy of Plio-Pleistocene sediments in a 1700-m core from Osaka Bay, southwestern Japan and short geomagnetic events in the middle Matuyama and early Brunhes chrons. Palaeogeogr. Palaeoclimatol. Palaeoecol. 148, 233-248.

Bokhorst, M.P., Beets, C.J., Marković, S.B., Gerasimenko, N.P., Matviishina, Z.N., Frechen, M., 2009. Pedochemical climate proxies in Late Pleistocene SerbianUkrainian loess sequences. Quat. Int. 198, 123-133.

Bokhorst, M.P., Vandenberghe, J., Sümegi, P., Lanczont, M., Gerasimenko, N.P., Matviishina, Z.N., Marković, S.B., Frechen, M., 2011. Atmospheric circulation patterns in Central and Eastern Europe during the Weichselian Pleniglacial inferred from loess grainsize records. Quat. Int. 234, 62-74.

Buggle, B., Hambach, U., Glaser, B., Gerasimenko, N., Marković, S.B., Glaser, I., Zöller, L., 2009. Magnetic susceptibility stratigraphy and spatial and temporal paleoclimatic trends in East European loess paleosol sequences. Quat. Int. 196, 86-106.

Buggle, B., Glaser, B., Hambach, U., Gerasimenko, N., Marković, S.B., 2010. An evaluation of geochemical weathering indices in loess-paleosol studies. Quat. Int. 240, $12-21$.

Buggle, B., Hambach, U., Kehl, M., Marković, S.B., Zöller, L., Glaser, B., 2013. The progressive evolution of a continental climate in SE-Central European lowlands during the Middle Pleistocene recorded in loess paleosol sequences. Geology 41, 771-774.

Channel, J.E.T., Raymo, M.E., 2003. Paleomagnetic record at ODP Site 980 (Feni Drift, Rockall) for the past 1.2 Myrs. Geochem. Geophys. Geosyst. 4 (4), 1033.

G. Csillag L. Fodor K. Sebe P. Müller Zs Ruszkiczay-Rüdiger E. Bozsó Thamóné G. Bada A 
szélerózió szerepe a Dunántúl negyedidőszaki felszínfejlődésében. (The role of wind abrasion in the Quaternary geomorphological evolution of Transdanubia) Földtani Közlöny 1402010463482

Ding, Z.L., Derbyshire, E., Yang, S.L., Yu, Z.W., Xiong, S.F., Liu, T.S., 2002. Stacked 2.6Ma grain size record formthe Chinese loess based on five sections and correlation with the deep-sea $\delta 180$ record. Paleoceanography 17. https://doi.org/10.1029/ 2001 PA000725.

Eger, A., Almond, P.C., Condron, L.M., 2012. Upbuilding pedogenesis under active loess deposition in a super-humid, temperate climate - quantification of deposition rates, soil chemistry and pedogenic thresholds. Geoderma 189-190, 491-501.

Members, E.P.I.C.A., 2004. Eight glacial cycles from an Antarctic ice core. Nature 429, 623-628.

Fiol, L.A., Fornós, J.J., Gelabert, B., Guijarro, J.A., 2005. Dust rains in Mallorca (Western Mediterranean): their occurrence and role in some recent geological processes. Catena 63, 64-84.

Fitzsimmons, K.E., Marković, S.B., Hambach, U., 2012. Pleistocene environmental dynamics recorded in the loess of the middle and lower Danube basin. Quat. Sci. Rev. 41, 104-118.

Földvári, M., Kovács-Pállfy, P., 2002. Mineralogical study of the Tengelic Formation and the Tolna Hegyhát and Mórágy Hills areas (Hungary). Acta Geol. Hungarica 45 (3), 247-263.

Gibbard, P.L., Cohen, K.M., 2008. Global chronostratigraphical correlation table for the last 2.7 million years. Episodes 31, 243-247.

Gilbert, R.O., 1987. Statistical methods for environmental pollution monitoring. Van Nostrand Reinhold, New York.

Hao, Q., Wang, L., Oldfield, F., Peng, S., Qin, L., Song, Y., Xu, B., Qiao, Y., Bloemendal, J., Guo, Z., 2012. Delayed build-up of Artic ice-sheets during 400,000-year minima in insolation variability. Nature 490, 393-396.

Head, M.J., Gibbard, P.L., 2005. Early-Middle Pleistocene transitions: an overview and recommendation for the defining boundary. In: Head, M.J., Gibbard, P.L. (Eds.), Early-Middle Pleistocene Transitions: The Land-Ocean EvidenceSpec. Publ. 247. Geological Society London, London, pp. 1-18.

Hoddel, D.A., Channell, J.E.T., 2016. Mode transitions in Northern Hemisphere glaciation: co-evolution of millenial and orbital variability in Quaternary climate. Clim. Past 12, 1805-1828.

Hodell, D.A., Channell, J.E.T., Curtis, J.H., Romero, O.E., Röhl, U., 2008. Onset of "Hudson Strait" Heinrich events in the eastern North Atlantic at the end of the middle Pleistocene transition ( $640 \mathrm{ka})$ ?". Paleooceanography 23.

Hovan, S.A., Steven, A., Rea, A., David, K., Pisias, K., Nicklas, G., 1991. Late Pleistocene continental climate and oceanic variability recorded in northwest Pacific sediments. Paleoceanography 6 (3), 349-370. https://doi.org/10.1029/91PA00559.

Hughes, P.D., Woodward, J.C., Gibbard, P.L., 2006. Late Pleistocene glaciers and climate in the Mediterranean region. Glob. Planet. Chang. 46, 83-98.

Hughes, P.D., Woodward, J.C., van Calsteren, P.C., Thomas, L.E., Adamson, K., 2010. Pleistocene ice caps on the coastal mountains of the Adriatic Sea: palaeoclimatic and wider palaeoenvironmental implications. Quat. Sci. Rev. 29, 3690-3708.

Hughes, P.D., Gibbard, P.L., Ehlers, J., 2013. Timing of glaciation during the last glacial cycle: evaluating the concept of a global'Last Glacial Maximum'(LGM). Earth-Sci. Rev. 125, 171-198.

Hungarian Meteorological Service: Climate Data Series 1901-2000, http://www.met.hu/ en/eghajlat/magyarorszag_eghajlata/eghajlati_adatsorok_1901-2000/, (last access: 20.10.15.).

Imbrie, J., Berger, A., Boyle, E.A., Clemens, S.C., Duffy, A., Howard, W.R., Kukla, G., Kutzbach, J., Martinson, D.G., McIntyre, A., Mix, A.C., Molfino, B., Morley, J.J., Peterson, L.C., Pisias, N.G., Prell, W.L., Raymo, M.E., Shackleton, N.J., Toggweiler, R., 1993. On the structure and origin of major glaciation cycles 2 . The 100,000-year cycle. Paleoceanography 8 (6), 699-735. https://doi.org/10.1029/93PA02751.

Isarin, R.F.B., Renssen, H., Koster, E.A., 1997. Surface wind climate during the Younger Dryas in Europe as inferred from aeolian records and model simulations. Palaeogeogr. Palaeoclimatol. Palaeoecol. 134, 127-148.

Jordanova, D., Petersen, N., 1999. Paleoclimatic record from a loess-soil profile in northeastern Bulgaria II. Correlation with global climatic events during the Pleistocene. Geophys. J. Int. 138, 533-540.

Jordanova, D., Hus, J., Geeraerts, R., 2007. Palaeoclimatic implications of the magnetic record from loess/palaeosol sequence Viatovo (NE Bulgaria). Geophys. J. Int. 171, 1036-1047.

Jordanova, D., Hus, J., Evgoliev, J., Geeraerts, R., 2008. Paleomagnetism of the loess/ paleosol sequence in Viatovo (NE Bulgaria) in the Danube Basin. Phys. Earth Planet. Inter. 167, 71-83.

Kageyama, M., Brierley, C., Crucifix, M., Hargreaves, J. C., Paul, A., Ramstein, G. (eds). 2012. Progress in paleoclimate modelling, Climate of the Past 9-10, special issue.

King, T., 1996. Quantifying non-linearity and geometry in time series analysis of climate. Quat. Sci. Rev. 15, 247-266.

Koloszár, L., 1997. Geological evaluation of the Udvari-2A borehole. Annual Report of the Geological Institute of Hungary 1996/II, 149-158.

Koloszár, L., 2003. DK-dunántúli negyedidőszaki képződmények környezetföldtani vizsgálata. (Environmental geological investigations of Quaternary sequences of SE Transdanubia). PhD thesis. University of Miskolc, 70 pp. (in Hungarian).

Koloszár, L., Lantos, M., 2001. DK-dunántúli negyedidőszaki szelvények magnetosztratigráfiai korrelációja (Magnetostratigraphic correlation of the Quaternary sequences in South-eastern Transdanubia). Földtani Közlöny 131, 221-231 (in Hungarian).

Koloszár, L., Marsi, I., 2010a. A Kárpát-medence legvastagabb és legteljesebb löszrétegsora: Az Udvari-2A fúrás szelvénye és kvarter rétegtani jelentősége. (The thickest and most complete loess sequence in the Carpathian Basin: the section of the borehole Udvari-2A and its significance in the Quaternary stratigraphy). Földtani Közlöny 140 (3), 251-262 (in Hungarian).

Koloszár, L., Marsi, I., 2010b. The thickest and most complete loess sequence in the Carpathian Basin: the borehole Udvari-2A. Cent. Eur. J. Geosci. 2 (2), 165-174.

Koloszár, L., Lantos, M., Chikán, G., 2001. A Görgeteg G-I és az Udvari U-2A fúrások negyedidőszaki képződményeinek párhuzamosítása. (Correlation of the Quaternary sediments in the Görgeteg G-I and the Udvari U-2A boreholes). Földtani Közlöny 131, 443-460 (in Hungarian).

Konert, M., Vandenberghe, J., 1997. Comparison of laser grain size analysis with pipette and sieve analysis: a solution for the underestimation of the clay fraction. Sedimentology 44 (3), 523-535.

Kohfeld, K.E., Harrison, S.P., 2000. How well can we simulate past climates? Evaluating the models using global palaeoenvironmental datasets. Quat. Sci. Rev. 19, 321-346.

Kuhleman, J., Rohling, E.J., Krumrei, I., Kubik, P., Ivy-Ochs, S., Kucera, M., 2008. Regional synthesis of Mediterranean atmospheric circulation during the last Glacial Maximum. Science 321, 1338-1340.

Kukla, G.J., 1975. Loess stratigraphy of Central Europe. In: Butzer, K.W., Isaac, L.I. (Eds.), After the Australopithecines. Mouton Publishers, The Hague, pp. 99-187.

Laj, C., Channel, J.E.T., 2009. Geomagnetic excursions. In: Kono, M. (Ed.), Treatise on Geophysics, Geomagnetism. Elsevier, Amsterdam, pp. 373-416.

Lambeck, K., Chappell, J., 2001. Sea level change through the last glacial cycle. Science 292 (5517), 679-686.

Lambert, F., Bigler, M., Steffensen, J.P., Hutterli, M., Fischer, H., 2012. Centennial mineral dust variability in high-resolution ice core data from Dome C, Antarctica. Clim. Past 8, 609-623.

Lang, N., Wolff, E.W., 2011. Interglacial and glacial variability from the last $800 \mathrm{ka}$ in marine, ice and terrestrial archives. Clim. Past 7, 361-380.

Langereis, C.G., Dekkers, M.J., De Lange, G.J., Paterne, M., Van Santvoort, P.J.M., 1997. Magnetostratigraphy and astronomical calibration of the: Last 1.1 Myr from an eastern Mediterranean piston core and dating of short events in the Brunhes. Geophys. J. Int. 129, 75-94.

Laskar, J., Robutel, P., Joutel, F., Gastineau, M., Correia, A.C.M., Levrard, B., 2004. A long term numerical solution for the insolation quantities of the Earth. Astron. Astrophys. 428, 261-285.

Lisiecki, L.M., Raymo, M.E., 2005. A Pliocene-Pleistocene stack of 57 globally distributed benthic $\delta^{18} \mathrm{O}$ records, Paleoceanography, 20, PA1003. Data archived at the World Data Center for Paleoclimatology, Boulder, Colorado, USA.

Lund, S.P., Williams, T., Acton, G.D.,Clement, B., Okada, M., 2001. Brunhes Chron magnetic field excursions recovered from Leg 172 sediments. In Keigwin, L.D., Rio, D. Acton, G.D., Arnold, E. (Eds.) Proc. ODP, Sci. Results 172, pp. 1-18.

Lund, S., Stoner, J.S., Channell, J.E.T., Acton, G., 2006. A summary of Brunhes paleomagnetic field variability recorded in Ocean Drilling Program cores. Phys. Earth Planet. Inter ODP Contribut. Paleomagnet. 156, 194-204.

Lu, H., An, Z., 1998. Palaeoclimatic significance of grain size of loess-paleosol sequence of Central China. Sci. China Ser. D 41, 626-631.

Lu, H., Zhang, F., Liu, X., Duce, R.A., 2004. Periodicities of paleoclimatic variations recorded by loess paleosol sequences in China. Quat. Sci. Rev. 23, 1891-1900.

Lüthi, D., Le Floch, M., Bereiter, B., Blunier, T., Barnola, J.M., Siegenthaler, U., Raynaud, D., Jouzel, J., Fischer, H., Kawamura, K., Stocker, T.F., 2008. High-resolution carbon dioxide concentration record 650,000-800,000 years before present. Nature 453, 379-382.

Machalett, B., Oches, E.A., Frechen, M., Zöller, L., Hambach, U., Mavlyanova, N.G., Marković, S.B., Endlicher, W., 2008. Aeolian dust dynamics in central Asia during the Pleistocene: Driven by the long-term migration, seasonality, and permanency of the Asiatic polar front. Geochem. Geophys. Geosyst. 9, Q08Q09. https://doi.org/10. 1029/2007GC001938.

Marković, S.B., Hambach, U., Catto, N., Jovanović, M., Buggle, B., Machalett, B., Zöller, L., Glaser, B., Frechen, M., 2009. The middle and late Pleistocene loess-paleosol sequences at Batajanica, Vojvodina, Serbia. Quat. Int. 198, 255-266.

Marković, S.B., Hambach, U., Stevens, T., Kukla, G.J., Heller, F., McCoy, W.D., Oches, E.A., Buggle, B., Zöller, L., 2011. The last million years recorded at the Stari Slankamen (Northern Serbia) loess-palaeosol sequence: revised chronostratigraphy and long-term environmental trends. Quat. Sci. Rev. 30, 1142-1154.

Marković, S.B., Hambach, U., Stevens, T., Basarin, B., O'Hara-Dhand, K., Gavrilov, M., Gavrilov, M., Smalley, I., Teofanov, N., 2012. Relating the astronomical timescale to the loess-paleosol sequences in Vojvodina, Northern Serbia. In: Berger, A., Mesinger, F., Sijacki, D. (Eds.), Climate Change: Inferences from Paleoclimate and Regional Aspects. Springer-Verlag, Vienna, pp. 65-78.

Marković, S.B., Stevens, T., Kukla, G.J., Hambach, U., Fitzsimmons, K.E., Gibbard, P., Buggle, B., Zech, M., Guo, Z., Hao, Q., Wu, H., O'Hara Dhand, K., Smalley, I.J., Újvári, G., Sümegi, P., Timar-Gabor, A., Veres, D., Sirocko, F., Vasiljevic, D.A., Jary, Z., Svensson, A., Jovic, V., Lehmkuhl, F., Kovács, J., Svircev, Z., 2015. Danube loess stratigraphy - towards a pan-European loess stratigraphic model. Earth-Sci. Rev. 148, 228-258.

Márton, P., 1998. Report of the results of paleomagnetic measurements of boreholes Udvari (U-2a) and Diósberény (Db-Ia). Manuscript. Hungarian Geological Institute (in Hungarian).

McClymont, E.L., Rosell-Mele, A., Haug, G.H., Lloyd, J.M., 2008. Expansion of subarctic water masses in the North Atlantic and Pacific oceans and implications for midPleistocene ice sheet growth. Paleoceanography 23, PA4214.

McClymont, E.L., Sosdian, S.M., Rosell-Mele, A., Rosenthal, Y., 2013. Pleistocene seasurface temperature evolution: early cooling, delayed glacial intensification, and implications for the mid-Pleistocene climate transition. Earth-Science Rev. 123, $173 \mathrm{e} 193$.

Menéndez, I., Pérez-Chacón, E., Mangas, J., Tauler, E., Engelbrecht, J.P., Derbyshire, E., Cana, L., Alonso, I., 2014. Dust deposits on La Graciosa Island (Canary Islands, Spain): texture, mineralogy and a case study of recent dust plume transport. Catena, Loess and dust dynamics, environments, landforms, and pedogenesis: a tribute to Edward Derbyshire 117, 133-144. https://doi.org/10.1016/j.catena.2013.05.007.

Middleton, N.J., Goudie, A.S., 2001. Saharan dust: sources and trajectories. Trans. Inst. Br. Geographers 26, 165-181. https://doi.org/10.1111/1475-5661.00013.

Murray, A.S., Schmidt, E.D., Stevens, T., Buylaert, J.P., Marković, S.B., Tsukamoto, S., Frechen, M., 2014. Dating Middle Pleistocene loess from Stari Slankamen (Vojvodina, Serbia) - limitations imposed by the saturation behaviour of an elevated temperature IRSL signal. Catena 117, 34-42. 
National Atlas of Hungary 2018 http://www.nemzetiatlasz.hu/.

Novothny, Á., Frechen, M., Horváth, E., Wacha, L., Rolf, C., 2011. Investigating the penultimate and last glacial cycles of the Süttó loess section (Hungary) using luminescence dating, high resolution grain size, and magnetic susceptibility data. Quat. Int. 234 (1-2), 75-85.

Nugteren, G., Vandenberghe, J., 2004. Spatial climatic variability on the Central Loess Plateau (China) as recorded by grain size for the last 250 kyrr. Glob. Planet. Change 41, 185-206.

Obrecht, I., Zeeden, C., Hambach, U., Veres, D., Marković, S.B., Bösken, J., Svirčev, Z., Bačević, N., Gavrilov, M.B., Lehmkuhl, F., 2016. Tracing the influence of Mediterranean climate on Southeastern Europe during the past 350,000 years. Scient. Rep. 6 (36334). https://doi.org/10.1038/srep36334.

Obrochta, S.P., Crowley, T.J., Channell, J.E.T., Hodell, D.A., Baker, P.A., Seki, A., Yokoyama, Y., 2014. Climate variability and ice-sheet dynamics during the last three glaciations. Earth Planet. Sci. Lett. 406, 198-212.

Panaiotu, C.G., Panaiotu, C.E., Grama, A., Necula, C., 2001. Paleoclimatic record from a loess-paleosol profile in southeastern Romania. Phys. Chem. Earth A 26, 893-898.

Pécsi, M., 1979. Lithostatigraphical subdivision of the loess profiles at Paks. Acta Geol. Hungar. 22, 409-418.

Pécsi, M., 1990. Loess is not just the accumulation of dust. Quat. Int. 7-8, 1-21.

Pécsi, M., 1993 Negyedkor és löszkutatás. (Quaternary and Loess Research), Akadémiai Kiadó, Budapest, Hungary, 375p. (in Hungarian).

Pécsi, M., Schweitzer, F., Balogh, J., Balogh, M., Havas, J., Heller, F., 1995. A new loess paleosol lithostratigraphical sequence at Paks (Hungary). Loess Form 3, 63-78.

Pye, K., 1995. Nature, origin and accumulation of loess. Quat. Sci. Rev. 14, 653-667.

Rădan, S.C., 2012. Towards a historical synopsis of dating the loess from the Romanian Plain and Dobrogea: authors and methods through time. GeoEcoMar 18, 153-172.

Rapp, D., 2012. Glacials and Interglacials: Measurement, Interpretation and Models. Springer-Verlag, Berlin doi: 10.1007/9783-642-30029-5-11.

Raymo, M.E., Lisiecki, L.E., Nisancioglu, K.H., 2006. Plio-Pleistocene ice volume, Antarctic climate, and the global $\delta^{18} \mathrm{O}$ record. Science 313, 492-495.

Rosenberg, P.D., Parker, D.J., Ryder, C.L., Marsham, J.H., Garcia-Carreras, L., Dorsey, J.R., Brooks, I.M., Dean, A.R., Crosier, J., McQuaid, J.B., Washington, R., 2014. Quantifying particle size and turbulent scale dependence of dust flux in the Sahara using aircraft measurements. J. Geophys. Res. Atmos. 119 1002/2013JD021255.

Royden, L., Horváth, F., 1988. The Pannonian Basin: A study in basin evolution. AAPG Memoir 45. American Association of Petroleum Geologists, Tulsa, Oklahoma, pp. 394.

Ruszkiczay-Rüdiger, Zs, Braucher, R., Csillag, G., Fodor, L.I., Dunai, T.J., Bada, G., Bourlés, D., Müller, P., 2011. Dating Pleistocene aeolian landforms in Hungary, Central Europe, using in situ produced cosmogenic 10Be. Quat. Geochronol. 6 (6), 515-529.

Ruszkiczay-Rüdiger, Z.s., Balázs, A., Csillag, G., Drijkoningen, G., Fodor, L., 2018a. PlioQuaternary uplift of the Transdanubian Range, Western Pannonian Basin: How fast and why? In: Sujan, M., Csibri, T., Kiss, P., Rybár, S. (Eds.), Environmental, Structural and Stratigraphical Evolution of the Western Carpathians Bratislava. Comenius University Press, pp. 94-95.

Ruszkiczay-Rüdiger, Z., Csillag, G., Fodor, L., Braucher, R., Novothny, Á., Thamó-Bozsó, E., Virág, A., Pazonyi, P., Tímár, G., ASTER Team, 2018. Integration of new and revised chronological data to constrain the terrace evolution of the Danube River (Gerecse Hills, Pannonian Basin). Quat. Geochronol. 48, 148-170.

Sartori, M., Heller, F., Forster, T., Borkovec, M., Hammann, J., Vincent, E., 1999. Magnetic properties of loess grain size fractions from the section at Paks (Hungary). Phys. Earth and Planet. Inter. 116, 53-64.

Schatz, A., Zech, M., Buggle, B., Gulyás, S., Hambach, U., Marković, S.B., Sümegi, P., Scholten, T., 2011. A late Quaternary loess record of Tokaj, Hungary: reconstructing palaeoenvironment, vegetaton and climate using stable $\mathrm{C}$ and $\mathrm{N}$ isotopes and biomarkers. Quat. Int. 240, 52-61.

Schatz, A., Scholten, T., Kühn, P., 2014. Paleoclimate and weathering of the Tokaj (NE Hungary) loess-paleosol sequence: a comparison of geochemical weathering indices and paleoclimate parameters. Clim. Past Discuss. 10, 469-507.

Schatz, A., Scholten, T., Kühn, P., 2015. Paleoclimate and weathering of the Tokaj (Hungary) loess-paleosol sequence. Palaeogeogr. Palaeoclimatol. Palaeoecol. 426, 170-182. https://doi.org/10.1016/j.palaeo.2015.03.016.

Schmidt, G.A., 2010. Enhancing the relevance of palaeoclimate model/data comparisons for assessments of future climate change. J. Quat. Sci. 25, 79-87.

Schmidt, E., Machalett, B., Marković, S.B., Tsukamoto, S., Frechen, M., 2010. Luminescence chronology of the upper part of the Stari Slankamen loess sequence (Vojvodina, Serbia). Quat. Geochronol. 5, 137-142.

Schulte, P., Spafke, T., Rodrigues, L., Fitzsimmons, K.E., 2018. Are fixed grain size ratios useful proxies for loess sedimentation dynamics? Experiences from Remizovka, Kazakhstan. Aeolian Res. 31, 131-140.

Schulz, M., Mudelsee, M., 2002. REDFIT: estimating red-noise spectra directly from un evenly spaced paleoclimatic time series. Comput. Geosci. 28, 421-426.

Sebe, K., Csillag, G., Ruszkiczay-Rüdiger, Zs, Fodor, L., Thamó-Bozsó, E., Müller, P., Braucher, R., 2011. Pleistocene periglacial mega-yardang system in Central Europe (Western Pannonian Basin, Hungary). Geomorphology 134, 470-482.

Singer, B.S., 2015. A Quaternary geomagnetic instability time scale. Quat. Geochronol. https://doi.org/10.1016/j.quageo.2013.10.003.

Smalley, I.J., Marković, S.B., 2014. Loessification and hydroconsolidation: there is a connection. Catena, Loess and dust dynamics, environments, landforms, and pedogenesis: a tribute to Edward Derbyshire 117, pp. 94-99.

Stevens, T., Markovic, S.B., Zech, M., Hambach, U., Sümegi, P., 2011. Dust deposition and climate in the Carpathian Basin over an independently dated last glacial-interglacial cycle. Quat. Sci. Rev. 30, 662-681.

Stevens, T., Carter, A., Watson, T.P., Vermeesch, P., Andò, S., Bird, A.F., Lu, H., Garzanti, E., Cottam, M.A., Sevastjanova, I., 2013. Genetic linkage between the Yellow River, the Mu Us desert and the Chinese Loess Plateau. Quatern. Sci. Rev. 78, 355-368.

Stevens, T., Buylaer, J.P., Thiel, C., Újvári, G., Yi, S., Murray, A.S., Frechen, M., Lu, H., 2018. Ice-volume forced erosion of the Chinese Loess Plateau global Quaternary stratotype site. Nat. Commun. 9, 983. https://doi.org/10.1038/s41467-018-03329-2.

Sun, Y.B., Clemens, S.C., An, Z.S., Yu, Z.W., 2006. Astronomical timescale and palaeoclimatic implication of stacked 3.6-Myr monsoon records from the Chinese Loess Plateau. Quat. Sci. Rev. 25, 33-48.

Sümegi, P., Gulyás, S., Persaits, G., 2011. Multiproxy paleoenvironmental analysis of long-term climatic fluctuations in Southwest Hungary reading terrestrial archives. XVIII. INQUA Congress, Bern, Switzerland. Quat. Int. 279-280, 477.

Sümegi, P., Gulyás, S., Molnár, D., Sümegi, B.P., Almond, P.C., Vandenberghe, J., Zhou, L., Pál-Molnár, E., Törőcsik, T., Hao, Q., Smalley, I., Molnár, M., Marsi, I., 2018. New chronology of the best developed loess/paleosol sequence of Hungary capturing the past 1.1 ma: Implications for correlation and proposed pan-Eurasian stratigraphic schemes. Quat. Sci. Rev. 191, 144-166.

Tari, G.C., Horváth, F., 2006. Alpine evolution and hydrocarbon geology of the Pannonian Basin: an overview. In: Golonka, J., Picha, F.J. (Eds.), The Carpathians and their foreland: geology and hydrocarbon resources. AAPG Memoir 84. American Association of Petroleum Geologists, Tulsa, pp. 465-478.

Thamó-Bozsó, E., Ó-Kovács, L., Magyari, A., Marsi, I., 2013. Tracing the origin of loess in Hungary with the help of heavy mineral composition data. Quat. Int. https://doi.org/ 10.1016/j.quaint.2013.04.030.

Thiel, C., Horváth, E., Frechen, M., 2014. Revisiting the loess/paleosol sequence of Paks in Hungary: a post-IR IRSL-based chronology for the "Young Loess Series". Quat. Int. 319, 88-98.

Torrence, C., Compo, G.P., 1998. A practical guide to wavelet analysis. Bull. Am. Meteorol. Soc. 79, 61-78.

Tzedakis, P.C., Hooghiemstra, H., Palike, H., 2006. The last 1.35 million years at Tenaghi Philippon: revised chronostratigraphy and long-term vegetation trends. Quat. Sci. Rev. 25, 3416-3430.

Újvári, G., Varga, A., Balogh-Brunstad, Z., 2008. Origin, weathering, and geochemical composition of loess in southwestern Hungary. Quat.Res. 69 421e437.

Újvári, G., Varga, A., Raucsik, B., Kovács, J., 2014. The Paks loess-paleosol sequence: a record of chemical weathering and provenance for the last $800 \mathrm{ka}$ in the midCarpathian Basin. Quat. Int. 319, 22-37.

Újvári, G., Kok, J.F., Varga, G., Kovács, J., 2016. The physics of wind-blown loess: implications for grain size proxy interpretations in Quaternary paleoclimate studies. Earth Sci. Rev. 154, 247-278. https://doi.org/10.1016/j.earscirev.2016.01.006.

Vandenberghe, J., Huijzer, B., Mücher, H., Laan, W., 1998. Short climatic oscillations in a western European loess sequence (Kesselt, Belgium). J. Quat. Sci. 13, 471-485.

Van Gijssel, K., 2006. A continent-wide framework for local and regional stratigraphies: application of genetic and event stratigraphy to the Middle Pleistocene terrestrial sediments of Northwest and Central Europe, Unpublished. PhD Thesis. University of Leiden, Leiden.

van Huissteden, K., Pollard, D., 2003. Oxygen isotope stage 3 fluvial and eolian successions in Europe compared with climate model results. Quat. Res. 59, 223-233.

Varga, Gy, 2011. Similarities among the Plio-Pleistocene terrestrial aeolian dust deposits in the world and in Hungary. Quat.Int. 234, 98-108.

Wacha, L., Frechen, M., 2011. The geochronology of the "Gorjanović loess section" in Vukovar. Croatia. Quat. Int. 240 (1-2), 87-99.

Wacha, L., Galović, L., Koloszár, L., Magyari, Á., Chikán, G., Marsi, I., 2013. The chronology of the Šarengrad II loess-palaeosol section (Eastern Croatia). Geol. Croat. 66 (3), 191-203.

Xiao, J., Porter, S.C., An, Z., Kumai, H., Yoshikawa, S., 1995. Grain size of quartz as an indicator of winter monsoon strength on the Loess Plateau of Central China during the last 130,000 yr. Quat. Res. 43, 22-29.

Yin, Q.Z., Berger, A., 2010. Insolation and $\mathrm{CO}_{2}$ contribution to the interglacial climate before and after the mid-Brunhes event. Nat. Geosci. 3, 243-246.

Zech, M., Zech, R., Zech, W., Glaser, B., Brodowski, S., Amelung, W., 2008. Characterization and paleoclimate of a loess-like permafrost paleosol sequence in NE Siberia. Geoderma 143, 281-295.

Zech, R., Zech, M., Marković, S., Hambach, U., Huang, Y., 2013. Humid glacials, arid interglacials? Critical thoughts on pedogenesis and paleoclimate based on multiproxy analyses of the loess-paleosol sequence Crvenka, Northern Serbia. Palaeogeogr. Palaeoclimatol. Palaeoecol. 387, 165-175.

Zeeden, C., Kels, H., Hambach, U., Schulte, P., Protze, J., Eckmeier, E., Marković, S.B., Klasen, N., Lehmkuhl, F., 2016. Three climatic cycles recorded in a loess-palaeosol sequence at Semlac (Romania) - Implications for dust accumulation in south-eastern Europe. Quat. Sci. Rev. 154, 130-142. https://doi.org/10.1016/j.quascirev.2016.11. 002.

Zeeden, C., Hambach, U., Obrecht, I., Hao, Q., Abels, H.A., Veres, D., Lehmkuhl, F., Gavrilov, M.B., Markovic, S.B., 2018. Patterns and timing of loess-paleosol transition in Eurasia: constraints for paleoclimate studies. Glob. Planet. Change 162, 1-7.

Zöller, L., 2010. New approaches to European loess: a stratigraphic and methodological review of the past decade. Cent. Eur. J. Geosci. 2 (1), 19-31. 